\title{
The Search for Solutions to Mysterious Anomalies in the Geologic Column
}

Hugh Miller $^{1 *}$, Robert Bennett ${ }^{2}$, Jean de Pontcharra ${ }^{3}$, Maciej Giertych ${ }^{4}$, Marie C. van Oosterwyck-Gastuche ${ }^{5}$, Otis Kline ${ }^{6}$, Bill White ${ }^{7}$, Hugh Owen $^{8}$ and Joe Taylor ${ }^{9}$

${ }^{1}$ Hugh Miller, retired from Battelle Memorial Institute, Columbus OH, currently a consulting chemist

${ }^{2}$ Robert Bennett, retired professor of physics, Bergen Community College, Paramus, N.J., currently a consulting physicist

${ }_{3}^{3}$ Jean de Pontcharra, retired atomic physicist, French Atomic Energy Commission, Grenoble Research Center, France

${ }^{4}$ Maciej Giertych, retired professor of population genetics, Institute of Dendrology, Polish Academy of Sciences, Kórnik, Poland

${ }^{5}$ Marie C. van Oosterwyck-Gastuche, retired mineralogist, The "Laboratoire des analyses" Department of mineralogy and geology of the Royal Museum for Central Africa, Tervuren, Belgium

${ }^{6}$ Otis Kline, field paleontologist, president and founder of the Glendive Dinosaur \& Fossil Museum, Glendive MT

${ }^{7}$ Bill White, electrical engineer, retired from 3L Communications, Columbus $\mathrm{OH}$

${ }^{8}$ Hugh Owen, educator and lecturer, director of The Kolbe Center, Mt. Jackson VA

9Joe Taylor, field paleontologist and director of the Mt. Blanco Fossil Museum, Crosbyton, TX

*Corresponding Author: Hugh Miller, Research chemist, Battelle Memorial Institute Rtd, 1215 Bryson Rd, Columbus Ohio, USA 43224; E-mail: hugoc14@aol.com

Received: November 29, 2019; Accepted: December 8, 2019; Published: December 21, 2019

\begin{abstract}
There is convincing evidence that soft tissue and other biomolecules have survived from the Mesozoic to the present, possibly because of their interaction with blood iron and/or carbonate adsorption. Here we present the results of investigations showing that ancient biomolecules and their decay products contain significantly higher percent Modern carbon $\left(\mathrm{pMC}={ }^{14} \mathrm{C} /{ }^{12} \mathrm{C}\right)$ values than diamond and coal. South African diamonds yielded pMC values of from 0.16 to $0.11 \mathrm{pMC}$, or ages of 52,000 to 55,000 Carbon- 14 years before present $\left({ }^{14} \mathrm{C}\right.$ years BP) [Baumgardner et al., 2003]. Ten coal specimens from the United States from Eocene and Pennsylvanian strata were 0.33 to $0.16 \mathrm{pMC}$, or 46,000 to $52,000{ }^{14} \mathrm{C}$ years BP. By comparison, our field and lab study of ten dinosaurs from Texas to Alaska plus China yielded much higher $\mathrm{pMC}$ 's of 6.50 to 0.61 , or 22,000 to $41,000{ }^{14} \mathrm{C}$ years $\mathrm{BP}$ after pretreatment to remove old and modern soil contaminants. The evidence for endogenous pMC was further enhanced by the $\delta^{13} \mathrm{C}$ range of -20.1 to -23.8 for collagen, -16.6 to -28.4 for bulk organic, and -3.1 to -9.1 for CO3 fractions. This data clarifies why such biomolecules have persisted. These unexpected results call for replication to determine whether they are anomalous. If not, the implication is that a portion of the geological time scale should be condensed, indicating a higher risk to Earth of meteorite impact due to greater frequency. We recommend systematic ${ }^{14} \mathrm{C}$ dating of similar samples taken from different parts of the entire geologic column.
\end{abstract}

Keywords: Bone, Carbon-14, Dating Fossil , Dinosaur, Radiocarbon

\section{Key points}

Significant endogenous ${ }^{14} \mathrm{C}$ was found in collagen and other fractions of dinosaur bones.

Thorough pretreatment of samples minimized potential contamination.

Confirmation through replication of our ${ }^{14} \mathrm{C}$ test results could have enormous implications for man and science.

\section{Introduction}

This paper is based on poster B31E-0068, displayed December 17 at the 2014 AGU meeting, entitled: "A Comparison of $\delta^{13} \mathrm{C}$ and pMC values for Ten Cretaceous-Jurassic Dinosaur Bones from Texas to Alaska USA, China and Europe with that of Coal and Diamonds presented in the $2003 \mathrm{AGU}$ meeting [1]. We also here include the pMC from the mosasaur reported by [2].

\section{Soft tissue and collagen in dinosaur bones}

In 2005, flexible soft tissue was reported in a Tyrannosaurus rex dinosaur femur bone [3], [4]. Further studies of other fossils confirmed that collagenous material was indeed endogenous in more than just the Tyrannosaurus rex femur. One such study by [2] discovered collagen in a marine reptile, a mosasaur. Accelerator Mass Spectrometer (AMS) ${ }^{14} \mathrm{C}$ dating at Lund University, Sweden, yielded a pMC of $4.68\left(24,600{ }^{14} \mathrm{C}\right.$ years $\left.\mathrm{BP}\right)$. We obtained collagen content of $0.35 \%$ extracted from cancellous bone in a Triceratops femur, and $0.2 \%$ collagen from cancellous bone in a Hadrosaur femur [5] (Table 1), with the former yielding a pMC of 2.16 , or $30,890 \pm 200$ ${ }^{14} \mathrm{C}$ years $\mathrm{BP}$, and the latter a pMC of 5.59 , or $23,170 \pm 170{ }^{14} \mathrm{C}$ years $\mathrm{BP}$. It is not unusual to ${ }^{14} \mathrm{C}$-date such a low amount of collagen, provided other bone fractions are tested and concordant ages are obtained, as 
Hugh Miller, Robert Bennett, Jean de Pontcharra, Maciej Giertych, Marie C. van Oosterwyck-Gastuche et al. (2019) The Search for Solutions to Mysterious Anomalies in the Geologic Column

described by [6]. Collagen was extracted from both dinosaur femurs and purified by the widely used "modified Longin method", which adds alkali to the Longin method [7]. The collagen content was the same as that for Kennewick Man’s first metatarsal: 0.3\% [8]. Kennewick Man, found along a river bank in Kennewick, Washington, was assigned a pMC of 35.1, or radiocarbon age of $8,410 \pm 40{ }^{14} \mathrm{C}$ years BP.

Table 1. ${ }^{14} \mathrm{C}$ Results for dinosaur bone collagen \& other fractions from TX to AK, Europe and China

\begin{tabular}{|c|c|c|c|c|c|}
\hline Dinosaur & Lab/method/fraction & ${ }^{14} \mathrm{C}$ Years B.P. & $\delta 13 \mathbf{C} / \mathbf{p M C}$ & Date of Report & Discovery Location \\
\hline (a) & (b) (c) & (d) & (e) & & \\
\hline 1. Acrocanthosaurus & GX-15155-A/Beta/bio & $>32,400$ & $-8.3 /<1.78$ & $1 / 10 / 1989$ & $\mathrm{TX}$ \\
\hline 2. Acrocanthosaurus & GX-15155-A-AMS/bio & $25,750 \pm 280$ & $-8.3 / 4.08$ & $6 / 14 / 1990$ & TX \\
\hline 3. Acrocanthosaurs & AA-5786-AMS/bio/scrape & $23,760 \pm 270$ & 15.22 & $10 / 23 / 1990$ & $\mathrm{TX}$ \\
\hline 4. Acrocanthosaurus & UGAMS-7509a/AMS/bio & $29,690 \pm 90$ & $-4.7 / 2.48$ & $10 / 27 / 2010$ & TX \\
\hline 5. Acrocanthosaurs & UGAMS-7509b/AMS/bow & $30,640 \pm 90$ & $-23.8 / 2.21$ & $10 / 27 / 2010$ & $\mathrm{TX}$ \\
\hline 6. Allosaurus & UGAMS-02947/AMS/bio & $31,360 \pm 100$ & $-6.6 / 1.98$ & $5 / 1 / 2008$ & $\mathrm{CO}$ \\
\hline 7. Hadrosaur \#1 & KIA-5523/AMS/bow & $31,050+230 /-220$ & $-28.4 / 2.10$ & $10 / 1 / 1998$ & AK \\
\hline 8. Hadrosaur \#1 & KIA-5523/AMS/hum & $36,480+560 /-530$ & $-25.5 / 1.07$ & $10 / 1 / 1998$ & AK \\
\hline 9. Triceratops \#1 & GX-32372-AMS/col & $30,890 \pm 200$ & $-20.1 / 2.16$ & $8 / 25 / 2006$ & MT \\
\hline 10. Triceratops \#1 & GX-32647-Beta/bow & $33,830+2910 /-1960$ & $-16.6 / 1.38$ & $9 / 12 / 2006$ & MT \\
\hline 11. Triceratops \#1 & UGAMS-04973a-AMS/bio & $24,340 \pm 70$ & $-3.1 / 4.83$ & $10 / 29 / 2009$ & MT \\
\hline 12. Triceratops \#2 & UGAMS-03228a-AMS/bio & $39,230 \pm 140$ & $-4.7 / 0.76$ & $8 / 27 / 2008$ & MT \\
\hline 13. Triceratops \#2 & UGAMS-03228b-AMS/이 & $30,110 \pm 80$ & $-23.8 / 2.36$ & $8 / 27 / 2008$ & MT \\
\hline 14. Triceratops \#3 & UGAMS-11752-AMS/bow & $33,570 \pm 120$ & $-17.1 / 1.53$ & $08 / 14 / 2012$ & MT \\
\hline 15. Triceratops \#3 & UGAMS-11752a-AMS/bio & $41,010 \pm 220$ & $-4.3 / 0.61$ & $08 / 14 / 2012$ & MT \\
\hline 16. Hadrosaur \#2 & GX-32739-Beta/ext & $22,380 \pm 800$ & $-16.0 / 6.19$ & $1 / 6 / 2007$ & MT \\
\hline 17. Hadrosaur \#2 & GX-32678/AMS/w & $22,990 \pm 130$ & $-18.4 / 5.74$ & $4 / 4 / 2007$ & MT \\
\hline 18. Hadrosaur \#2 & UGAMS-01935/AMS/bio & $25,670 \pm 220$ & $-6.4 / 4.09$ & $4 / 10 / 2007$ & MT \\
\hline 19. Hadrosaur \#2 & UGAMS-01936/AMS/w & $25,170 \pm 230$ & $-15.7 / 4.36$ & $4 / 10 / 2007$ & MT \\
\hline 20. Hadrosaur \#2 & UGMAS-01937/AMS/col & $23,170 \pm 170$ & $-22.7 / 5.59$ & $4 / 10 / 2007$ & MT \\
\hline 21. Hadrosaur \#3 & UGAMS-9893/AMS/bio & $37,660 \pm 160$ & $-4.9 / 0.93$ & $11 / 29 / 2011$ & ND \\
\hline 22. Stegosaurus & UGAMS-9891/AMS/bio & $38,250 \pm 160$ & $-9.1 / 0.86$ & $11 / 29 / 2011$ & $\mathrm{CO}$ \\
\hline 23. Psittacosaur & UGAMS-8824/AMS/bio & $22,020 \pm 50$ & $-5.4 / 6.45$ & $5 / 21 / 2011$ & China \\
\hline 24. Mosasaur & Lund, Sweden AMS Lab(f) & 24,600 & $/ 4.8$ & 2011 & Belgium \\
\hline
\end{tabular}

\section{FOOTNOTES TO TABLE 1}

a) Acrocanthosaurus, a carnivorous dinosaur excavated in 1984 near Glen Rose TX by C. Baugh and G. Detwiler; in 108 Ma Cretaceous sandstone; identified by Dr. W. Langston of the University of TX at Austin.

Allosaurus, a carnivorous dinosaur excavated in 1989 by J. Hall and A. Murray. It was found under an Apatosaurus skeleton in the Wildwood section of a ranch west of Grand Junction CO in $150 \mathrm{Ma}$ (Late Jurassic) sandstone of the Morrison Formation.

Hadrosaur \#1, a duck billed dinosaur. Bone fragments were excavated in 1994 along the Colville River by G. Detwiler and J. Whitmore in the Liscomb bone bed of the Alaskan North Slope; identified by J. Whitmore. 
Hadrosaur \#2, a duck billed dinosaur. A femur bone was excavated in 2004 in clay in the NW 1/4, NE 1/4 of Sec. 32, T16N, R56 E, Dawson County, Montana by O. Kline of the Glendive Dinosaur and Fossil Museum. It was sawed open by O. Kline and H. Miller in 2005 to retrieve samples for C-14 testing.

Triceratops \#1, a ceratopsid dinosaur. A femur bone was excavated in 2004 in Cretaceous clay at $47^{\circ}$ 6' 18” by 104 39' 22” Montana by O. Kline of the Glendive Dinosaur and Fossil Museum. It was sawed open by O. Kline,

H. Miller in 2005 to retrieve samples for C-14 testing.

Triceratops \#2, a very large ceratopsid-type dinosaur excavated in 2007 in Cretaceous clay at 47'02" 44N and 104' 32" 49W by O. Kline of Glendive Dinosaur and Fossil Museum. Outer bone fragments of a femur were tested for C-14.

Triceratops \#3, a large (40 inch) brow horn was excavated in 2012 in Cretaceous clay at SW 1/4 of NE 1/4 of Sec. 14, T 15 N, R 56 E, Dawson County, Montana, elevation 2240 feet on a private ranch by a team led by O. Kline of Glendive MT Dinosaur and Fossil Museum. The outer bone fragments were tested for $\mathrm{C}-14$ content. We asked for carbon and nitrogen content - Bulk C was 1.8 and $\mathrm{N} 0.05 \%$.

Hadrosaur \#3, a duck billed dinosaur. Scrapings were taken from a large bone in Colorado in Cretaceous strata, excavated by J. Taylor of Mt. Blanco Fossil Museum, Crosbyton TX.

Stegosaurus. Scrapings were taken from a rib still imbedded in the clay soil of a ranch in CO, partially excavated in 2007 and 2009 , in $150 \mathrm{Ma}$ (Late Jurassic) strata by C. Baugh and B. Dunkel; identified by C. Baugh in 2014

Psittacosaurus, a small ceratopsian dinosaur whose name means "parrot lizard". The tail bone is from the Gobi Desert, donated by Mt. Blanco Museum. Mosasaur - see Lindgren et al. 2011.

b) GX is Geochron Labs, Cambrdge, MA; AA is the University of Arizona, Tuscon, AZ; UG is the University of Georgia, Athens, GA; KIA is Christian Albrechts Universität, Kiel, Germany; AMS is Accelerator Mass Spectrometry; Beta is the conventional method of counting Beta decay particles; Bio is the carbonate fraction of bioapatite. Bow is the bulk organic fraction of whole bone; Col is the collagen fraction; ext and w are charred exterior and whole bone fragments, respectively; Hum is humic acid.

c) Weight of samples:

Sample size sent to RC lab, $\approx 170 \mathrm{~g}$ as required by Geochron in 1990 for GX-15155, conventional beta.

Sample size sent to RC lab, excess CO2 from GX-15155 encapsulated in glass and sent to a lab in New Zealandfor AMS testing.

Sample size sent to RC lab, $\approx 50 \mathrm{mg}$ scrapings from Acro bone for AA-5786, AMS Sample size sent to RC lab, $6.4 \mathrm{~g}$ from femur for UGAMS-7509a \& b, AMS Sample size sent to RC lab, $\approx 30 \mathrm{~g}$ for UGAMS-02947, AMS

Sample size sent to $\mathrm{RC}$ lab, $\approx 5 \mathrm{~g}$ for KIA-5523, AMS.

Sample size sent to RC lab, 146 g for GX-32647 - outer bone, conventional beta Sample size sent to RC lab, 2.3 g for GX-31950 - internal bone, AMS.

Sample size sent to RC lab, 160 g for GX-32678-AMS \& GX-32739 - outer bone, Conventional beta Sample size sent to RC lab, 56 g for UGAMS-01935, 01936, 01937,01938 - internal bone, AMS.

d) The quoted uncalibrated dates have been given in ${ }^{14} \mathrm{C}$ years BP (Before Present, i.e. 1950), using the ${ }^{14} \mathrm{C}$ half- life of 5568 years (conversion formulae: age $=(5568$ years $)(\log 2(100 \% / \mathrm{pMC}))$ and $\mathrm{pMC}=(100 \%)\left(2^{\wedge}\right.$ - age/5568). The plus-or-minus range is one standard deviation and reflects both statistical and experimental errors. The dates have been corrected for isotope fractionation.

e) $\delta^{13} \mathrm{C}$ is expressed by the formula $\delta^{13} C_{\text {Sample }}=\left(\frac{{ }^{13} C /{ }^{12} C_{\text {Sample }}}{{ }^{13} C /{ }^{12} C_{\text {PDB }}}-1\right) \cdot 1000$

The $\mathrm{pMC}$ is the percent of Modern ${ }^{14} \mathrm{C}$ in the dinosaur bone fractions, such as collagen and bioapatite.

f) A sample of Mosasaur bone was pretreated to remove contaminants to test for carbon content in the Lund University AMS laboratory in Lund, Sweden [Lindgren et al., 2011]. The resultant original carbon content of the bone was $0.25 \%$, and the $14 \mathrm{C}$ content was also reported, as noted in this table and discussed in the text.

\section{Endogenous wood in calcareous material}

"Calcareous fossils" were excavated from a coalmine in Nova Scotia in 1846 [9]. Using dilute hydrochloric acid to dissolve the calcareous materials yielded "flexible woody material" that was also burnable. He reported that the cavities of the cells were filled with "carbonate of lime", and that a common specimen contained " $45 \%$ carbonate of lime, $27.5 \%$ proto-carbonate of iron, $1.0 \%$ carbonaceous material." Thus carbonate apparently helped preserve the original wood, and may have a similar preservative effect on dinosaur soft tissue.

\section{${ }^{14} \mathrm{C}$ in a mosasaur, a Cretaceous marine reptile}

A well-preserved mosasaur humerus found in Belgian chalk beds yielded $0.25 \%$ carbon content and a pMC of 4.68 , which corresponds to an age of $24,600{ }^{14} \mathrm{C}$ years BP [2], as noted above. Standard acidbase-acid (ABA) pre-treatment was used to remove contaminants such as calcite and humic acid before AMS testing, making contamination an extremely unlikely ${ }^{14} \mathrm{C}$ source. This age was questioned by the investigating team, which attributed the anomalous age to possible cyanobacteria on the bone surface, although no bacterial proteins or hopanoids were detected. However, even if cyanobacteria were present, they would likely be contemporaneous with the mosasaur upon whose bones they fed, i.e. Cretaceous.

\section{${ }^{14} \mathrm{C}$ in coals from the USA and diamonds from South Africa}

Coals from various locations in the United States, as reported by [1], yielded pMC values of 0.33 to $0.11\left(\sim 45,000\right.$ to $55,000{ }^{14} \mathrm{C}$ years $\mathrm{BP})$. The authors observed that: "Averaged over geological interval, the AMS determinations yielded remarkably similar values of $0.26 \mathrm{pMC}$ for the Eocene, 0.21 for the Cretaceous and 0.27 for the Pennsylvanian samples." Diamonds from South Africa, on the other hand, yielded lesser amounts of pMC ranging from 0.15 to 0.1 ( 52,000 to 55,000 ${ }^{14} \mathrm{C}$ years BP). Compare with Tables 3 and 4 from [1]. These dates are in the range considered to be at the limit of AMS reliability. 


\section{${ }^{14} \mathrm{C}$ in diamonds from South America}

Thirteen diamond samples from Brazil yielded pMC's of 0.026 to 0.005 , or ${ }^{14} \mathrm{C}$ ages of 66,500 to $80,000{ }^{14} \mathrm{C}$ years BP [10].

\section{Significant ${ }^{14} \mathrm{C}$ content in unfossilized wood and Pleistocene mammals}

Wood obtained from an oil geologist, who had extracted it from an Upper Cretaceous drill core deep in the permafrost of Prudhoe Bay, Alaska, yielded a pMC of $0.45, \delta^{13} \mathrm{C}$ of -24.8 and an age of 43,380 $\pm 380{ }^{14} \mathrm{C}$ years BP on an AMS unit reliable up to a pMC of 0.2 or 50,000 years. It was removed from a $50 \mathrm{~cm}$-diameter tree at a depth of $36 \mathrm{~m}$ [Table 2, \#4, GX-30816-AMS, 2004]. Two samples from a tree branch of tamarack wood from $122 \mathrm{~m}$ depth were radiocarbon dated to a pMC of 4.2 and 2.6 , or $25,500 \pm 1000$ and $29,200 \pm 2000{ }^{14} \mathrm{C}$ years $\mathrm{BP}$, [11] using $\beta$-scintillation counting. Another unfossilized wood sample from $143 \mathrm{~m}$ depth gave a pMC of 0.43 , or an age of $>43,300$
${ }^{14} \mathrm{C}$ years BP using $\beta$-scintillation counting [12]. The "soft tissue" collagen fraction of a bone sample from a Coelodonta antiquitatais (wooly rhinoceros), found in Ukraine in 1929 yielded a pMC of 5.56, or $23,235 \pm 775{ }^{14} \mathrm{C}$ years $\mathrm{BP}$ when tested by $\beta$ - scintillation counting following pretreatment with benzene, ethyl alcohol, then $2 \mathrm{~N} \mathrm{HCl} \mathrm{[13].}$ The range of pMC's for ten saber tooth tigers from La Brea Tar Pits, pretreated to remove tar, is 9.4 to 3.1 ( 12,000 to 28,000 year range) [14]. The ages for collagen from an ancient bison and dire wolf reported by [15] were 2.17 and 3.1 pMC, or 30,819 \pm 975 and 27,920 $\pm 650{ }^{14} \mathrm{C}$ years BP respectively, excavated from the same site in Yukon Territory, Canada. Storage facilities for cores from drilling activities in permafrost regions of Alberta, Canada, the United States, and other portions of the Northern Hemisphere are fertile ground for wellpreserved fossils for ${ }^{14} \mathrm{C}$ dating. Oil companies are in a position to advance such research in the Alaskan tundra, with interest in samples down to 683 meters, the maximum depth of the permafrost.

Table 2. Results for ${ }^{14} \mathrm{C}$ in wood, coal, amber and soil.

\begin{tabular}{|c|c|c|c|}
\hline $\begin{array}{l}\text { Lab I.D., Type of wood, amber, or coal, Soil } \\
\text { and Location }\end{array}$ & $\begin{array}{c}\text { Formation/Geologic } \\
\text { Age. } \mathrm{Ma}\end{array}$ & $\begin{array}{l}\delta 13 C / p M C \\
\text { (a) }\end{array}$ & $\begin{array}{l}\text { 14C Age } \\
\text { (Years) }\end{array}$ \\
\hline 1.A-4856- $\beta$ Carbonized, TX (b) & Cretaceous, 108 & $-20.9 / 0.93$ & $37,480+2950 /-3250$ \\
\hline A-4855- $\beta$ Acro site, TX (c) & Cretaceous, 108 & $-20.9 / 0.33$ & $45,920+5650 /-3280$ \\
\hline A-3167- $\beta$ Carbonized, TX (d) & Cretaceous, 108 & $-22.4 / 0.96$ & $37,420+6120 /-3430$ \\
\hline limestone rock (e) & Cretaceous, 108 & $-22.4 / 0.20$ & $>49,900$ \\
\hline \multicolumn{4}{|l|}{ X-31367-AMS Carbonized, TX } \\
\hline 3.GX-31,730-AMS Carbonized, CO (f) & Jurassic, 150 & $-23.4 / 0.41$ & $44,200 \pm 2100$ \\
\hline 4.GX-30816-AMS Unfossilized, AK (g) & Cretaceous? 65 & $-24.8 / 0.46$ & $43,380 \pm 380$ \\
\hline 5.GX-30932 Mumm-AMS, Canada (h) & Cretaceous? 65 & $-25.2 / 0.34$ & $>45,700$ \\
\hline 6.KIA-14899 Mumm-AMS, Canada (i) & Cretaceous? 65 & $-23.2 / 0.14$ & $52,820+3680 /-2510$ \\
\hline 7.UGAMS-02442 Lignite, MT (j) & Cretaceous? 65 & $-27.5 / 0.52$ & $42,560 \pm 340$ \\
\hline 8.GX-32371-AMS Fern, MT (k) & Cretaceous, 68 & $-25.0 / 0.36$ & $45,190+9300 /-4200$ \\
\hline 9.UGAMS-02442 Soil-T, MT (1) & Cretaceous, 68 & $-24.4 / 8.51$ & $19,820 \pm 80$ \\
\hline 10.UGAMS-17706 Soil-R, MT (m) & Cretaceous, 68 & $-24.7 / 2.77$ & $28,820 \pm 130$ \\
\hline 11.UGAMS-11764 Coal, Europe(n) & Pennsylvanian, 225 & $-24.7 / 0.2$ & $49,690 \pm 640$ \\
\hline 12. KIA-2963 Amber in Tri strata (o) & Cretaceous, 68 & $-24.01 / 0.31$ & $>46,450$ \\
\hline KIA-2961 Amber Saxony (p) & Upper Oligocene, 30 & $-22.11 / 0.22$ & $>49,210$ \\
\hline KIA-2962 Amber, Russia (q) & Upper Eocene, 40 & $-21.88 / 0.10$ & $>55,690$ \\
\hline 13. UGAMS-5838 Shale, CO (r) & Lower Eocene, 50 & $-31.0 / 0.37$ & $45,130 \pm 270$ \\
\hline
\end{tabular}

Footnotes to Table 2

a) $\delta^{13} \mathrm{C}$ is expressed by the formula $\delta^{13} C_{\text {Sample }}=\left(\frac{{ }^{13} \mathrm{C} /{ }^{12} C_{\text {Sample }}}{{ }^{13} \mathrm{C} /{ }^{12} C_{\mathrm{PDB}}}-1\right) \cdot 1000$, while pMC is the percent of Modern ${ }^{14} \mathrm{C}$ in the dinosaur bone fractions, such as collagen and bioapatite.

b) Report dated 09/28/1987 “Charcoal” or carbonized wood in Cretaceous clay, TX; Hugh Miller and Dr. John DeVilbiss, collectors.

c) Report dated 09/28/1987 "coalified wood" in Cretaceous rock or clay associated with the Acrocanthosaurus burial site along the Paluxy River, TX; Dr. John Devilbiss, collector. 
d) Report dated 6/14/1990 "Charcoal" or carbonized wood in Cretaceous clay, TX. As in footnote (a), it was discovered in clay between Cretaceous limestones, each containing dinosaur footprints; Mrs. John Whitmore and Hugh Miller, collectors.

e) Report dated 02/02/2006 "Carbonized wood" in Cretaceous limestone from TX. Calcite in the rock could have "aged" the wood extracted from limestone above the clay by absorbing old carbon; Hugh Miller, collector.

f) Report dated 06/01/2005 "Coalified wood" attached to petrified wood from CO. The bark apparently resisted mineralization but not coalification or carbonization; Bill White and Joe Guthrie, collectors.

g) Report dated 03/26/2004 "Unfossilized wood" from $36 \mathrm{~m}$ depth in side-wall of a 6 meter diameter storage pit, North Slope of AK. This wood was removed from a 0.6 meter-diameter $\log$.

h) Report dated 08/03/2004 "Mummified wood", Ellef Ringnes Island, CA; Canadian geologist Dr. Charles Felix, collector.

i) Report dated 10/10/2001 "Mummified wood", Ellef Ringnes Island, CA. The pMC was only $0.14 \pm 0.05$, similar to some diamonds and coal; humic acid fraction 17,580 $\pm 90{ }^{14} \mathrm{C}$ years BP, corrected pMC 11.21 \pm 0.12 ; Canadian geologist Dr. Charles Felix, collector.

j) Report dated 12/17/2007, from a lignite lens in MT, UGAMS-02442-AMS, $12.78 \%$ carbon, 42,560 \pm 340 , pMC $0.52 \pm 0.02$. The Cretaceous lignite sample was 200 feet above wood from the fern tree \#11; Otis Kline, collector.

k) Report dated 03/16/2006 "Fern tree wood" in Cretaceous clay, Glendive, MT, GX-32371-AMS, 45,190 + 9300/-4200; Hugh Miller and Bill White, collectors.

1) Report dated 12/17/2007, "Soil" surrounding Triceratops \#1 femur. The ${ }^{14} \mathrm{C}$ age is from the soil in which the Triceratops was buried, demonstrating that the fossil bone had not become appreciably contaminated with younger material. This increases confidence in RC ages of the dinosaur bones; Otis Kline, collector.

m) Report dated 06/17/2014, "Soil" surrounding a juvenile Tyrannosaurus rex femur bone. The ${ }^{14} \mathrm{C}$ age from the 60,000 year-sensitive AMS unit is from the original soil in which the femur was buried, and demonstrates that the fossil bone had not become appreciably contaminated with younger material, as it is older than the soil sample in footnote 1). The bone itself was returned by the University of Georgia's AMS lab without processing, so the ${ }^{14} \mathrm{C}$ age of the Tyrannosaurus rex remains unknown.

n) Report dated 07/31/2012, "Coal" sample dredged from the bottom of Atlantic Ocean from the wreck of the HMS Titanic with authentication by the president of the Titanic Association; collector, Hugh Miller.

o) Report dated 10/31/1997, “Amber" (cedarite) was from a Triceratops burial site in eastern Wyoming called the "Dragon's Graveyard." Although as much as 9,000 years younger than amber from Europe in RC years, it was allegedly 68 Ma old; collectors, Joe Taylor and Hugh Miller.

p) Report dated 10/31/1997, "Amber" (cedarite) from Saxony, Germany; collector Dr. Barbara Kosmowska- Ceranowicz, curator of the amber collection in The Museum of the Earth in Warsaw, Poland. See Kosmowska- Ceranowicz et al. [2001].

q) Report dated 10/31/1997, “Amber” (cedarite) from Russia; collector, Dr. Barbara Kosmowska-Ceranowicz.

r) Report dated 03/03/2010, "Shale" from the Early Eocene Green River Formation, CO, containing $10.88 \%$ carbon. ${ }^{14} \mathrm{C}$ dated on the 60,000-year-sensitive AMS unit at the University of Georgia; collector, Beatrice Herlacher

\section{Materials}

\section{Neanderthals:}

Typical ages and pMC's for fossil carbon are plotted in Figure 1. Neanderthal fossils throughout Europe and Asia have been radiocarbon dated [16], [17]. The time of final extinction is uncertain, but current estimates indicate roughly $40,000{ }^{14} \mathrm{C}$ years $\mathrm{BP}$, or a pMC or 0.69 .

\section{Mammoths bones}

[18] radiocarbon dated 363 mammoth bone, tusk, teeth and soft tissue samples from many sites in Eurasia. The temporal distribution was fairly even between 10,000 and $40,000{ }^{14} \mathrm{C}$ years BP (pMC's of 28.8 and 0.69 ), with fewer dating from 45,000 to $50,000{ }^{14} \mathrm{C}$ years $\mathrm{BP}$ (pMC's of 0.37 to 0.2 ). Figure 1 shows an average age of these mammoths as $19,000{ }^{14} \mathrm{C}$ years BP for those dated to $<40,000{ }^{14} \mathrm{C}$ years BP. There is a mammoth burial site in Hot Springs, South Dakota, containing the remains of 50 animals about which the authors wrote: "The warm spring waters that infiltrated the sinkhole leached out the collagen in the bones." Only the calcium carbonate from bioapatite remained for ${ }^{14} \mathrm{C}$ dating; it yielded $3.9 \mathrm{pMC}$, or an age of $26,000{ }^{14} \mathrm{C}$ years $\mathrm{BP}$ [19]. The Mt. Blanco Fossil Museum director, a coauthor of this paper, submitted mammoth and mastodon bone samples for ${ }^{14} \mathrm{C}$ dating at the University of Georgia. The ages are shown under Results.

\section{Dinosaur bones}

Samples from a total of ten dinosaurs have been ${ }^{14} \mathrm{C}$ dated from Texas, Colorado, Montana, North Dakota, and Alaska, producing pMC's of 5.7 to 0.61 (23,000 to $41,000{ }^{14} \mathrm{C}$ years BP), as shown in Table 1 , Table 3 is concerned with $\delta^{13} \mathrm{C}$, and supports the reliability of the ${ }^{14} \mathrm{C}$ ages. [20] found nitrogen content in 24 samples of bones from various species of dinosaurs found in the Late Cretaceous Judith River Formation in Alberta, Canada that was much higher than the nitrogen content of any of our dinosaur bones.

\section{Wood}

We analyzed wood samples and other fossil material from the Eocene to the Jurassic for ${ }^{14} \mathrm{C}$ content, including unfossilized wood from Alaska, carbonized wood from Texas, coal from Europe, lignite from the Union Formation in Montana, and Cretaceous mummified wood from Canada (Table 2).

\section{Coal}

[1] selected ten coal samples from the U.S. Department of Energy Coal Sample Bank maintained at Penn State University. The coals in this bank are intended to be representative of the economically important coal fields of the United States. The original samples were collected from recently exposed areas of active mines, placed in 30 
gallon steel drums with high-density gaskets, and purged with argon. Their important data are in Table 4, which reflects Table 2 from [1]. The $1 \mathrm{~cm}$-diameter sample of coal we tested for ${ }^{14} \mathrm{C}$ content was purchased from the souvenir shop of the Titanic shipwreck exhibit, authenticated by the president of the exhibit (Table $2 \# 11$ ). Since the Titanic loaded coal from both England and France for her maiden voyage the mine from which the coal was dug is unknown. More coal from disparate locations should be tested for ${ }^{14} \mathrm{C}$ content.

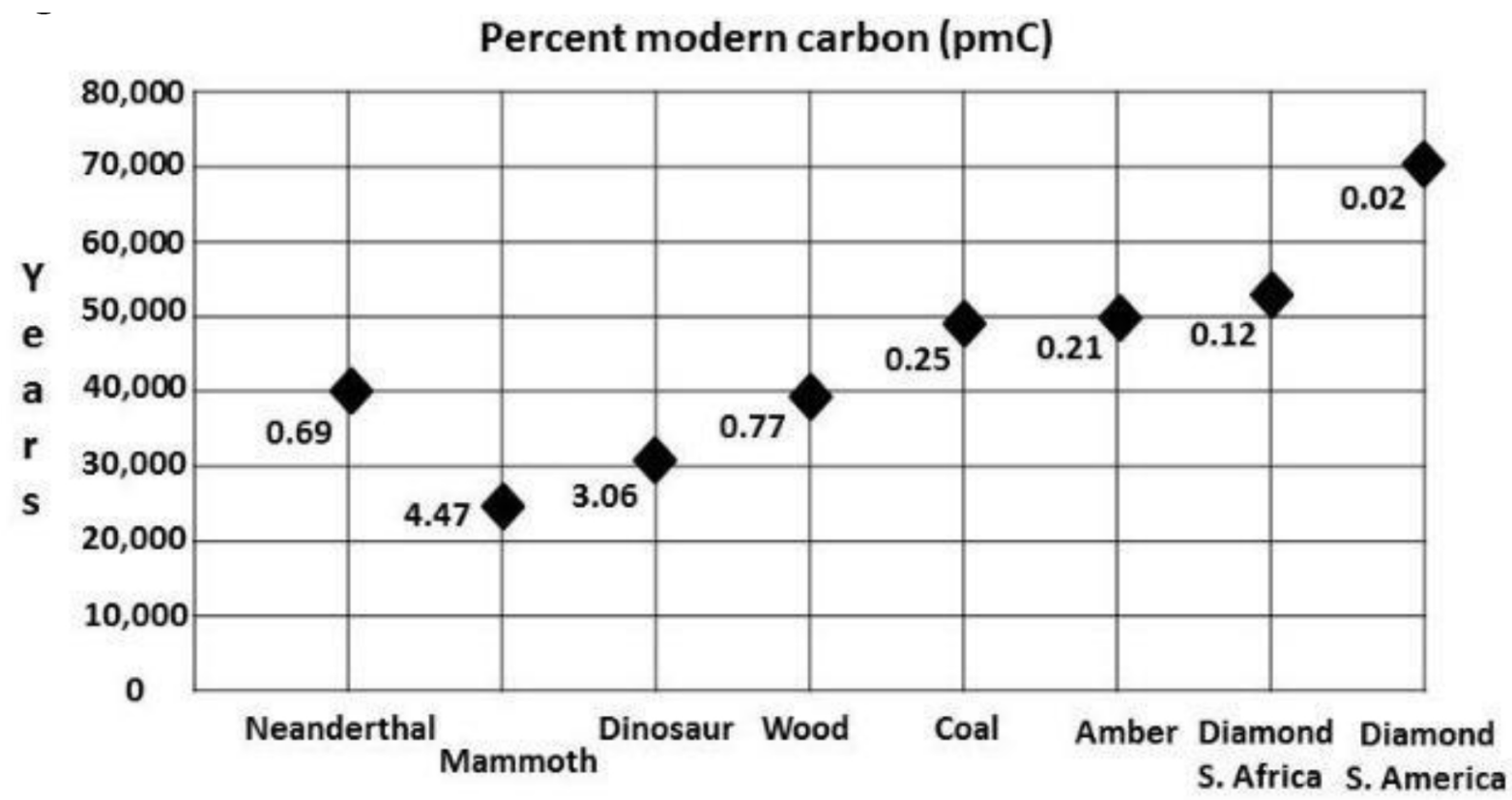

Figure 1. Typical ages of AMS and conventional $\beta$ for various fossils and diamonds.

Table 3. $\delta{ }^{13} \mathrm{C}$ for dinosaur bones

\begin{tabular}{|c|c|c|}
\hline \multicolumn{3}{|c|}{$\delta^{\mathbf{1 3}} \mathbf{C}$ for dinosaur bones ${ }^{(\mathbf{a})}$} \\
\hline Collagen & $\begin{array}{c}\text { Collagen \& Biproducts } \\
\text { (bulk organic fraction) }\end{array}$ & $\begin{array}{c}\text { Endogenous Carbonate } \\
\text { from Bioapetite }\end{array}$ \\
\hline-23.8 & -23.8 & -8.3 \\
\hline-20.1 & -28.4 & -4.7 \\
\hline-22.7 & -16.1 & -6.6 \\
\hline & -16 & -3.1 \\
\hline & -18.4 & -4.7 \\
\hline-22.5 & -15.7 & -6.4 \\
\hline average & -19.7 & -5.4 \\
\hline
\end{tabular}

\section{Amber}

We removed small pieces of amber imbedded in clay next to a triceratops skeleton in the Hell Creek Cretaceous Formation in a region of Wyoming sometimes referred to as the "Dinosaur Graveyard". Coauthor M. Giertych submitted samples of the amber for ${ }^{14} \mathrm{C}$ testing and coauthored a report on the results [21]. Two other pieces of amber from Saxony and Russia were chosen for ${ }^{14} \mathrm{C}$ dating from the amber collection of the Museum of the Earth, Warsaw, Poland. These results were published by the Museum of the Earth. The above amber samples are fossilized tree resin known as cedarite, and chemically as succinite. The ${ }^{14} \mathrm{C}$ results are shown in Table $2 \# 12$ and averaged for Figure 1.

\section{Diamonds}

One set of five diamonds are from South Africa [1] and the other set of four diamonds are from South America [10]. The results of AMS ${ }^{14} \mathrm{C}$ analysis of these nine diamonds are listed in Figure 1 and Table 5 with their pMC values and ages in years for comparison with other fossils such as dinosaurs, fossil wood, coal and amber shown in Figure 1.

\section{Methods}

Four different AMS labs and one conventional $\beta$ lab were utilized in ${ }^{14} \mathrm{C}$-dating 24 bone samples from 11 dinosaurs (Table 1), nine samples of fossil wood, three samples of amber, two soil samples, one coal sample, one lignite sample, and one shale sample, all giving ages in thousands of years. The labs are operated by: the University of Arizona; Geochron Laboratories in Massachusetts; Christian Albrechts Universität, Germany; the University of Georgia; and an AMS subcontractor for Geochron Laboratories in New Zealand, and are listed in the footnotes of Table 1. A sixth lab Lund University, Lund Sweden was used by [2] to test for original carbon content. The modified Longin method of [7] for extracting collagen was used by labs that ${ }^{14} \mathrm{C}$-dated the dinosaur bones. It combines two methods of purification as described in a typical lab report as follows: "The bones were mechanically cleaned and washed, then pulverized and treated 
at low temperature $\left(4-6^{\circ} \mathrm{C}\right)$ by $2-3$ fresh solutions of $0.5-1.0 \mathrm{~N} \mathrm{HCl}$ for a few days (depending on preservation condition) until mineral components dissolved completely. We washed the collagen obtained in distilled water until no Calcium was detectable. We then treated the collagen with $0.1 \mathrm{~N} \mathrm{NaOH}$ at room temperature for $24 \mathrm{~h}$ and washed it again in distilled water until neutral. We treated the collagen with a weak $\mathrm{HCl}$ solution $(\mathrm{pH}=3)$ at $80-90^{\circ} \mathrm{C}$ for $6-8 \mathrm{~h}$. Finally, we separated the humic acid residue from the gelatin solution by centrifugation, and the solution was evaporated. Benzene was synthesized from the dried gelatin by burning in a 'bomb' or by dry pyrolysis, using the standard methods...." .The pretreatment procedures used for particular samples can be found in "Original Lab Reports" in the Acknowledgement section.[7] reported that this procedure yielded older ages because the bone samples were more purified than when the component methods were employed separately. The ages of bones he tested for ${ }^{14} \mathrm{C}$ content were not from dinosaurs, and his results ranged up to $27,000{ }^{14} \mathrm{C}$ years $\mathrm{BP}$. Following the University of Georgia's upgrade of the sensitivity of their AMS equipment from 0.37 to 0.10 pMC (45,000 to $55,000{ }^{14} \mathrm{C}$ years BP) in 2008 , the age for Hadrosaur \#3 in 2011 was $37,660 \pm 160$, whereas the age for the Hadrosaur \#2 femur bone yielded an age of $23,170 \pm 170$ years in 2007 . We point this out so that the reader is not confused by the differences in \pm values as related to the ${ }^{14} \mathrm{C}$ ages. In some cases we also asked the labs to give us the $\mathrm{N}$ and $\mathrm{C}$ content. At the time, this was not considered necessary; however, we now recommend it. When using AMS, it is necessary to separate different dinosaur bone fractions such as collagen, $\mathrm{CaCO} 3$ from bioapetite, total collagen and collagen breakdown products, and specific separate and extracted contaminants so as to ensure that endogenous ${ }^{14} \mathrm{C}$ is identified. It is theoretically possible to count every atom of carbon with AMS, so the assessment of ${ }^{14} \mathrm{C}$ content should be very accurate. As demonstrated by [10], the addition of machine background to pMC values is negligible; it will not materially affect pMC values for dinosaur bones or even coal.

Table 4. Results of ${ }^{14} \mathrm{C}$ analyses of ten coal samples.

\begin{tabular}{|l|l|l|l|l|c|}
\hline \multicolumn{1}{|c|}{ Sample } & \multicolumn{1}{|c|}{ Coal Seam } & \multicolumn{1}{|c|}{ State } & County & \multicolumn{1}{c|}{$\begin{array}{c}\text { Geological } \\
\text { Interval }\end{array}$} & ${ }^{14} \mathbf{C} / \mathbf{C}(\mathbf{p m C})$ \\
\hline DECS-1 & Bottom & Texas & Freestone & Eocene & $0.30 \pm 0.03$ \\
DECS-11 & Beulah & North Dakota & Mercer & Eocene & $0.20 \pm 0.02$ \\
DECS-25 & Pust & Montana & Richland & Eocene & $0.27 \pm 0.02$ \\
DECS-15 & Lower Sunnyside & Utah & Carbon & Cretaceous & $0.35 \pm 0.03$ \\
DECS-16 & Blind Canyon & Utah & Emery & Cretaceous & $0.10 \pm 0.03$ \\
DECS-28 & Green & Arizona & Navajo & Cretaceous & $0.18 \pm 0.02$ \\
DECS-18 & Kentucky \#9 & Kentucky & Union & Pennsylvanian & $0.46 \pm 0.03$ \\
\hline DECS-21 & Lykens Valley \#2 & Pennsylvania & Columbia & Pennsylvanian & $0.13 \pm 0.02$ \\
\hline DECS-23 & Pittsburgh & Pennsylvania & Washington & Pennsylvanian & $0.19 \pm 0.02$ \\
\hline DECS-24 & Illinois \#6 & Illinois & Macoupin & Pennsylvanian & $0.29 \pm 0.03$ \\
\hline
\end{tabular}

From: Baumgardner et al. [2003]

Table 5. Results of ${ }^{14} \mathrm{C}$ analyses of nine diamond samples.

\begin{tabular}{|c|c|}
\hline $\begin{array}{c}\text { South African } \\
\text { Diamonds (pMC) }\end{array}$ & $\begin{array}{c}\text { South African Diamonds } \\
\text { (Years) }\end{array}$ \\
\hline 0.138 & 52,994 \\
\hline 0.105 & 55,194 \\
\hline 0.12 & 54,119 \\
\hline 0.146 & 52,541 \\
\hline 0.096 & 55,915 \\
\hline
\end{tabular}

Reference: Baumgardner et al. [2003]

\begin{tabular}{|c|c|}
\hline $\begin{array}{c}\text { S. American Diamonds } \\
\text { (pMC) }\end{array}$ & $\begin{array}{c}\text { S. American Diamonds } \\
\text { (Years) }\end{array}$ \\
\hline 0.031 & 64,900 \\
\hline 0.005 & 80,000 \\
\hline 0.018 & 69,300 \\
\hline 0.015 & 70,600 \\
\hline
\end{tabular}

Reference: Taylor and Southon [2007] "Use of natural diamonds to monitor C-14 AMS instrument backgrounds." Nuclear Instruments and Methods in Physics Research B, 259(1), 282-287. 


\section{Results}

\section{${ }^{14} \mathrm{C}$ in Neanderthals}

Although we did not date Neanderthal fossils, we referenced ${ }^{14} \mathrm{C}$ data from other scientists [15]. Carbon-14 ages for Neanderthal bones range from 2.4 to $0.2 \mathrm{pMC}\left(30,000\right.$ to $50,000{ }^{14} \mathrm{C}$ years $\left.\mathrm{BP}\right)$.

\section{${ }^{14} \mathrm{C}$ in mammoths}

The ages for the mammoth and mastodon bone samples submitted by the Mt. Blanco Fossil Museum were 1.04 and 5.34 pMC, or 36,700 \pm 210 [UGAMS-02684] and 23,560 $\pm 100{ }^{14}$ C years BP, [UGAMS-02766] respectively. Like the mammoths from Hot Springs, South Dakota [Thompson and Agenbroad, 2005], they contained no collagen, so the calcium carbonate of the bioapatite was ${ }^{14} \mathrm{C}$ dated as recommended by [22] and [23].

\section{${ }^{14} \mathrm{C}$ in dinosaur bones}

The modified Longin method of [7] for extracting collagen yielded -24.8 for $\delta^{13} \mathrm{C}$ and ages of $2.15 \mathrm{pMC}$, or $30,890 \pm 200{ }^{14} \mathrm{C}$ years $\mathrm{BP}$ (using an AMS system with 45,000 year reliability) for an interior bone sample from Triceratops \#1 [GX32372, Table 1]. For the Hadrosaur \#2 femur bone [UGAMS01937, Table 1], the results were -22.7 for $\delta^{13} \mathrm{C}$ and pMC of $5.61(23,170 \pm 170){ }^{14} \mathrm{C}$ years BP using the same AMS system. These ages are similar to those which [6] obtained for mammal bones. Figure 1, entitled "Age results of AMS \& Conventional $\beta$ for various fossils," includes Neanderthals, mammoths, dinosaurs, wood, coal, amber, and diamonds.

\section{${ }^{14} \mathrm{C}$ in wood}

The pMC results for wood from Cretaceous and Jurassic strata varied more than those for coal, and generally contained higher pMC values, as shown in Table 3. Although the dates of some fossils approached the upper limit of the more sensitive AMS systems, we concluded that they contained endogenous ${ }^{14} \mathrm{C}$, as did [1] for coal and South African diamonds.

\section{${ }^{14} \mathrm{C}$ in coal}

[1]argue that the coal and even diamonds they tested contain intrinsic ${ }^{14} \mathrm{C}$, and that although recorded pMC's were low (as shown in Figure 1 and Tables 4 and 5) it was not due to systematic instrument error (as demonstrated by [10] or contamination. Shale from an Eocene formation in Colorado contained $10.88 \%$ carbon, yielding a similar age to that of younger coal at $0.37 \mathrm{pMC}$, or $45,130 \pm 270{ }^{14} \mathrm{C}$ years BP (Table $2 \# 13$ ).

\section{${ }^{14} \mathrm{C}$ in amber}

The results shown in Table $2 \# 12$ indicate that all three specimens fall in the same range as coal from Europe (Table 2 \#11) and ten samples of American coal. These are noted in Table 4 [1] for comparison. Amber found in the same Cretaceous clay matrix as the triceratops produced the youngest of the three ${ }^{14} \mathrm{C}$ ages for amber in Table 2. Although near the AMS detection limit, the ${ }^{14} \mathrm{C}$ is evidently endogenous to the amber, as it apparently is to the dinosaur bones and coal.

\section{${ }^{14} \mathrm{C}$ in diamonds}

The data show that the tested samples of coal, dinosaur bones, and South African diamonds have higher pMC's than the South American diamonds from Brazil used as test blanks by [10], who concluded that the bulk of ${ }^{14} \mathrm{C}$ in their South American diamonds is endogenous. This suggests that ${ }^{14} \mathrm{C}$ is endogenous to all of the above.

\section{Summary of results}

1. The primary result is that all the dinosaur, wood, coal, shale and the younger amber samples, appear to contain significant amounts of ${ }^{14} \mathrm{C}$, which was demonstrated to be endogenous and not due to contamination or systematic instrument error.

2. The average ${ }^{14} \mathrm{C}$, or $\mathrm{pMC}$, content (Figure 1) varies from one fossil type to another, the youngest being dinosaur bones. Wood, amber, and coal are intermediate and the oldest are diamonds. Although this trend seems to indicate relative ages for each group, additional testing is needed due to the relatively small number of samples of each type tested. In addition, there may exist freshwater reservoir effects (see discussion).

3. There were no significant pMC differences between Cretaceous and Jurassic dinosaur fossils, although only two Jurassic samples were tested.

4. The range of ${ }^{14} \mathrm{C}$ ages for 363 mammoth samples (pMC 33 to 0.16 , or 9,000 to $52,000{ }^{14} \mathrm{C}$ years $\mathrm{BP}$ ) is similar to that of samples from eleven dinosaurs (pMC 6.5 to 0.61 , or 22,000 to $41,000{ }^{14} \mathrm{C}$ years BP).

5. The range of ${ }^{14} \mathrm{C}$ ages for fossil wood (Table 2) from Cretaceous and Jurassic strata is 0.96 to $0.14 \mathrm{pMC}$, or 37,000 to $52,000{ }^{14} \mathrm{C}$ years BP. Many more fossil wood samples need to be ${ }^{14} \mathrm{C}$ dated.

6. Our $\delta^{13} \mathrm{C}$ values compare favorably to those in a similar study of dinosaur $\delta^{13} \mathrm{C}$ values (-23 to -27) from the Judith River formation in Alberta, Canada [20] See Table 3.

\section{Discussion}

\section{Avoiding ${ }^{14} \mathrm{C}$-dating of dinosaur bones in the past}

To determine the age of bones, it is common practice to radiocarbon date extracted collagen or carbonate from bioapatite. Yet until now this has not been done with dinosaur bones because they are assumed to have become extinct at least 65 million years ago and therefore are too old for radiocarbon dating. The existence of dinosaurs in "deep time" has been taught to science students for over 100 years, with the result that they have not searched for evidence that dinosaurs existed relatively recently. Our curiosity was aroused by anomalies such as the presence of carbon on the surface of dinosaur bones and the carbon dating of wood found in Cretaceous formations containing dinosaur footprints (Table 2, \#1). Consequently, we concluded that if these anomalous ${ }^{14} \mathrm{C}$ ages were correct, then dinosaur bones could only be thousands of years old as well. Similarly, [14] curiosity was aroused by finding collagen in Saber Tooth Tigers in the La Brea Tar Pits. They ${ }^{14} \mathrm{C}$ dated the collagen after suitable pretreatments to remove the tar and learned that the bones were much younger than assumed. Best practice to ascertain an age for a given fossil bone is to ${ }^{14} \mathrm{C}$ date 
the bone first and then ${ }^{14} \mathrm{C}$ date other bone fractions and associated material to determine whether concordance emerges, as scientists did to obtain the correct chronology for the "Ice Man" found in northern Italy. Carbon-14 testing by AMS determined that his bones and associated items dated to $5300{ }^{14} \mathrm{C}$ years BP [24].

\section{The importance of $\delta{ }^{13} \mathrm{C}$ fraction ratio}

Animals normally derive their $\delta^{13} \mathrm{C}$ from plants and/or animals they ingest, and this should reflect their food supply. Table 3 shows $\delta^{13} \mathrm{C}$ values that cluster by fraction. These fractions are collagen by itself, collagen and by- products (bulk organic fraction) and calcium carbonate of bioapatite. The collagen fractions of three dinosaur bones from southern Montana were miniscule (0.35, 0.2 and $0.1 \%$ ) but were still dateable and the ages were concordant with other bone fractions as shown in Table 1. The carbonate portion of bioapatite was about $0.6 \%$ and these fractions fell in the range of -3.1 to -9.1 per mil for $\delta{ }^{13} \mathrm{C}$, whereas the organic fraction showed $\delta^{13} \mathrm{C}$ values ranging from -15.7 to -28.4 per mil. The bioapatite values were in the expected range for carbonate minerals derived from atmospheric carbon dioxide, which contains $\delta^{13} \mathrm{C}$ values around -7.0 per mil. We also found organic $\delta^{13} \mathrm{C}$ values near the expected range for most C3 plants as a consequence of photosynthesis (-24 to -34 per mil). The collagen samples showed an even tighter cluster of $\delta^{13} \mathrm{C}$ values closer to expected plant organics, ranging from -20.1 to -23.8 per mil. The more enriched organic $\delta^{13} \mathrm{C}$ values came from collagen and bulk organic fractions of whole bone (-15.7 to -18.4 per mil). The significant isotopic differences between $\delta^{13} \mathrm{C}$ in bioapatite versus organic fractions fall within, or close to, the expected values for each component of bone, based on preferential uptake into organics such as proteins. Bioapatite crystal structure constrains its constituents, limiting uptake of the oversized ${ }^{13} \mathrm{C}$ atoms during construction. Extant bone thus holds more ${ }^{13} \mathrm{C}$ than bioapatite fractions, as these dinosaur bones do. Because these $\delta^{13} \mathrm{C}$ values fall near the range of modern values for bioapatite carbonate and organic compounds and because the dinosaur material is obviously much more ancient than modern bone, some degree of modern contamination cannot be completely ruled out. However, the discovery of a realistic $\delta^{13} \mathrm{C}$ fractionation ratio is consistent with the hypothesis that our measured ${ }^{14} \mathrm{C}$ is endogenous, confirming the many reports by others of endogenous fossil soft tissue and collagen. As noted in section 2.3, [18] found significant nitrogen content in well preserved bones of 42 Cretaceous species, including dinosaurs, in Alberta, Canada. The nitrogen content for 15 species of fish and aquatic reptiles was $-1.0 \%$ to $11.6 \% \mathrm{~N}$ content, with a mean of $7.2 \% \pm 1$; a mean of $5.4 \% \pm 3$ for 16 species of amphibians and mesofauna; a mean of $4.7 \% \pm 0.5$ for 5 species of Hadrosaurids; and a mean of $6.6 \% \pm 0.4$ for 6 species of Tyranosaurids. $\delta^{13} \mathrm{C}$ values for these 42 species were in the normal range of -23 to -27 , but the Nitrogen- 15 levels for the Canadian dinosaurs were much larger than any of our samples from the United States, which contained no more than $0.35 \%$ (for Triceratops \#1). Since collagen holds over $95 \%$ of the nitrogen in bones [25], this suggests the presence of a significant amount of collagen in the Canadian dinosaur bones. According to the findings of [26], the adjusted nitrogen content in metatarsal bones from 28 human skeletons dating to circa 1000 B.C. near Canimar Abajo, Cuba ranged from $5.8 \%$ to $10.4 \%$. Collagen content for these bones ranged from 4.2 to $13 \%$ giving a ratio of about 1:1 N to Collagen. Interestingly, the Canadian dinosaur bones were located in a region that was under ice during the Last Glacial Maximum (LGM), whereas the bones of the ten dinosaurs we had radiocarbon dated were not under ice during the LGM. If further investigation finds enhanced preservation of collagen in dinosaur bones under glacial ice for thousands of years, it reinforces the timeframe for burial indicated by our radiocarbon dates. We recommend that all dinosaur bones be tested for nitrogen content as well as carbon content. If $\sim 0.3 \%$ or higher collagen content is discovered, then the extracted collagen should be ${ }^{14} \mathrm{C}$ dated (following pretreatment), provided bulk bone and/or bioapatite fractions are also dated to see if essential concordance is obtained, as urged by [5].

\section{Contaminants - new and old carbon}

Table 6 is about dealing with possible contaminants. These include burial carbonate, humic acid and preservatives. For example, adsorbed old or young burial carbonate is removed by dilute acetic acid under vacuum by professional labs. They also routinely remove old or young humic acids with dilute hot alkali. At our request, they isolated and then ${ }^{14} \mathrm{C}$ dated several contaminants as listed in Table 7. Note that those contaminants and all others had been removed before dating. Therefore, we feel confident that our ${ }^{14} \mathrm{C}$ ages are as accurate as can be achieved. These licensed, professional laboratories follow the protocols developed over a period of 60 years, as reported in the journal Radiocarbon [20] and elsewhere. Shellac and other fossil preservatives are removed by refluxing in organic solvents at high temperature. However, "old" carbon from recycled $\mathrm{CO} 2$, with less ${ }^{14} \mathrm{C}$ than the atmosphere, can make a sample appear older than it really is. Old carbon (with a low ${ }^{14} \mathrm{C} /{ }^{12} \mathrm{C}$ ratio) ingested during lifetime cannot be removed. Therefore, in some instances, ${ }^{14} \mathrm{C}$ ages of living plants and trees reflect the intake of old carbon. An example of this was found in living plants in Montezuma Well in Arizona, where the plants yielded pMC's of 12.1 to 5.1 (17,000 to $24,000{ }^{14} \mathrm{C}$ years BP) [27]. Ages for these live plants growing in well water devoid of $\mathrm{C} 14$ are in Radiocarbon Journal 1964, pages 93-94: A-438 Modern Aquatic plant (Charophyceae) growing under water, 17,300+/-400 years; and Potamogeton illinoensis roots on floor but reach water surface, 24,750 $+/-400$ years. In another case, a living tree growing at a German airport absorbed fossil fuel gases from passing planes. It yielded a pMC of 28.8 , or a ${ }^{14} \mathrm{C}$ age of $10,000{ }^{14} \mathrm{C}$ years BP [28]. There has been an ongoing debate over the reliability of ${ }^{14} \mathrm{C}$ dating carbonate fractions of bone bioapatite depleted of collagen and in very poor condition due to environmental degradation $[22,29,30]$. At issue is the exchange of original carbon in bioapatite with environmental carbon, leading to a change, mostly younger, in the radiocarbon age. The dinosaur bones we sampled were in good to very good condition or, rarely, petrified, so we doubt that our ${ }^{14} \mathrm{C}$ ages would be much affected, although differences in pMC's between samples from different parts of the same bone could be influenced by this effect. This view is supported by the concordance of pMC's among the dinosaur bones we dated, as shown in Figure 7, where we compare the percent of Modern ${ }^{14} \mathrm{C}$ (pMC) in 23 samples of dinosaur bone fractions extracted primarily by AMS labs. The samples have the same identifiers in both Table 1 and Figure 7. 
Hugh Miller, Robert Bennett, Jean de Pontcharra, Maciej Giertych, Marie C. van Oosterwyck-Gastuche et al. (2019) The Search for Solutions to Mysterious Anomalies in the Geologic Column

As shown in Figure 7, the pMC concordance between fractions from the same dinosaur (six examples are circled) indicates that almost all contaminants were removed by the pretreatment procedures used. Whether the samples were extracted from the same bone or from different parts of the same dinosaur, we obtained reproducible and concordant pMC's. Note that some bioapatite ages were older than bulk bone or collagen in the same bone, as with Triceratops \#2 (12 and 13), Triceratops \#3 (14 and 15), and Hadrosaur \#2 (18 and 20) in Table 1. Dating collagen and bone apatite in permafrost regions or regions formerly covered by glaciers could shed more light on this matter. Accelerator Mass Spectrometry laboratories strive to both achieve and assess maximum sensitivity and accuracy in their operations. An experiment to examine the level of machine background error was conducted using diamonds from Paleozoic alluvial deposits in Brazil, with assumed ages well over 100 million years and thus presumed to completely lack ${ }^{14} \mathrm{C}$ content [8] Thirteen diamond samples yielded pMC's of 0.026 to 0.005 , or ${ }^{14} \mathrm{C}$ ages of 66,500 to $80,000{ }^{14} \mathrm{C}$ years BP. Interestingly, they found that: "Six fragments cut from a single diamond exhibited essentially identical ${ }^{14} \mathrm{C}$ values $-69.3 \pm 0.5 \mathrm{ka}-$ $70.6 \pm 0.5 \mathrm{ka}{ }^{14} \mathrm{C}$ years BP." However, the other diamonds exhibited a range of $68.1 \pm 1.2 \mathrm{ka}$ to $80.0 \pm 1.1 \mathrm{ka}$. They wrote that "it is not clear to us what factors might be involved in the greater variability in the apparent ${ }^{14} \mathrm{C}$ concentrations exhibited in individual diamonds as opposed to splits from a single natural diamond." ${ }^{114} \mathrm{C}$ from the actual sample is probably the dominant component of the 'routine' background."

Table 6. Possible contaminants, pretreatments, mitigations, and contaminants detected

\begin{tabular}{|c|c|c|}
\hline Possible Contaminants (a) & Pretreatments And/Or Alternate Tests Performed & $\begin{array}{l}\text { Contaminant } \\
\text { Detected }\end{array}$ \\
\hline Young burial carbonate (b) & Hot dilute Acetic acid under vacuum (h) & None \\
\hline Old burial carbonate & Hot dilute Acetic acid under vacuum & None \\
\hline Young Humic acid (c) & Hot dilute acid-base-acid (ABA) (i) & None \\
\hline Old Humic acid & Hot dilute acid-base-acid (ABA) & None \\
\hline Collagen impurities & $\begin{array}{l}\text { Tested other bone fractions for reproducibility and/or tested } \\
\text { for }{ }^{14} \mathrm{C} \text { in extracted precipitate from alkaline liquid (j) }\end{array}$ & None \\
\hline In-situ bone carbonate & $\begin{array}{l}\text { After removal of burial carbonate, the bone sample is treated } \\
\text { in dilute } \mathrm{HCl} \text { under vacuum to collect } \mathrm{CO} 2 \text { for testing for }{ }^{14} \mathrm{C} \text { content }(\mathrm{k})\end{array}$ & None \\
\hline $\begin{array}{l}\text { Cluster decay of } \mathrm{U} \& \text { Th causing } \\
\qquad \mathrm{N} \text { of collagen into }{ }^{14} \mathrm{C}(\mathrm{d})\end{array}$ & Analysis for $\mathrm{U}$ and Th showed only ppm $\mathrm{U}$ and Th in bones that contained small amounts of collagen. (l) & None \\
\hline Incomplete removal of Contaminants (e) & Reproducibility among multiple labs and between bone fractions (m) & None \\
\hline Shellac type preservatives on museum bones (f) & $\begin{array}{l}\text { Refluxed in a mix of two hot organic solvents until discolorations dissipated, followed by ABA etc. removes } \\
\text { shellac, glue and PVC coatings (n) }\end{array}$ & None \\
\hline Reservoir effect causing possible old ages (g) & $\begin{array}{l}\text { Source of nutrition during lifetime of dinosaurs cannot be determined, therefore the }{ }^{14} \mathrm{C} \text { ages are considered } \\
\text { the oldest possible ages }\end{array}$ & None \\
\hline Bacteria and fungus & $\begin{array}{l}\text { According to RC Laboratories bacteria is removed by ABA pretreatment. Plus, microbes would be the same } \\
\text { age as the bones they feed upon (o) }\end{array}$ & None \\
\hline${ }^{14} \mathrm{C}$ signature an artifact of low sample numbers & Age concordance between 25 separate ${ }^{14} \mathrm{C}$ ages & None \\
\hline $\begin{array}{l}{ }^{14} \mathrm{C} \text { signatures an artifact of geological or geo- } \\
\text { graphical province }\end{array}$ & $\begin{array}{l}\text { Age concordance between dinosaur material from eight widely divergent geographical and geological prov- } \\
\text { inces }\end{array}$ & None \\
\hline $\begin{array}{l}{ }^{14} \mathrm{C} \text { signatures an artifact of sampling location } \\
\text { on fossil }\end{array}$ & Age concordance between samples collected from a variety of locations within bone samples & None \\
\hline $\begin{array}{l}{ }^{14} \mathrm{C} \text { signature an artifact of faulty or outdated } \\
\text { detection technique }\end{array}$ & $\begin{array}{l}\text { Age concordance between samples tested by AMS sensitive to } 45 \mathrm{ka} \text {, AMS sensitive to } 60 \mathrm{ka} \text {, and Beta count- } \\
\text { ing technologies }\end{array}$ & None \\
\hline $\begin{array}{l}{ }^{14} \mathrm{C} \text { concordance an artifact of inadequate sample } \\
\text { size }\end{array}$ & Sample sizes ranged from $0.05 \mathrm{~g}$ to $160 \mathrm{~g}$ with concordant ${ }^{14} \mathrm{C}$ fractions & $\begin{array}{l}\text { Sometimes, with } \\
\text { Beta detection }\end{array}$ \\
\hline${ }^{14} \mathrm{C}$ signature a result of inadequate sample prep & $\begin{array}{c}24 \text { samples prepared with acid/base/acid wash yielded concordant pMCs. Three poorly prepared samples } \\
\text { yielded discordant pMCs }\end{array}$ & $\begin{array}{l}\text { Yes, without acid/ } \\
\text { base/acid prewash }\end{array}$ \\
\hline
\end{tabular}

a. Bone fragments to be tested for ${ }^{14} \mathrm{C}$ content are first crushed to $\mathrm{mm}$-size particles before pretreatment designed to remove potential contaminants.

b. Young or old carbonates can be adsorbed on bones during burial and are removed from surfaces by dilute Acetic acid without disturbing the carbonate within the bones that form during the lifetime of the dinosaur.

c. Young or old humic acids from new or old vegetation are easily removed by alkali (base). When total organics, including collagen, are being dated, that portion of the bone sample is treated with dilute $\mathrm{HCl}$ to remove both burialand in-situ carbonate. Collagenis extracted by theArslanovmethoddiscussedintext. Ifthecollagenisnot a golden color or the percent of collagen is very low or non-existent, as in most dinosaur bones, then other portions of the bone are extracted for total organics and/or in-situ biological carbonate for testing for ${ }^{14} \mathrm{C}$ content to ensure reproducibility and reliability. 
Hugh Miller, Robert Bennett, Jean de Pontcharra, Maciej Giertych, Marie C. van Oosterwyck-Gastuche et al. (2019) The Search for Solutions to

Mysterious Anomalies in the Geologic Column

d. Nuclear production of up to $1.0 \mathrm{pMC}$ from the presence of large amounts of $\mathrm{U}$ and $\mathrm{Th}$ cannot occur in dinosaur bones, which contain small amounts of $\mathrm{U}$ and Th impurities, because the atomic cross sections are too low.

e. Incomplete removal of organic contaminants could result in ages in the thousands of years, but concordant ${ }^{14} \mathrm{C}$ ages in the range of 22,000 to 31,000 ${ }^{14} \mathrm{C}$ years $\mathrm{BP}$ from five different labs testing a variety of fractions makes contamination unlikely. Using three ABA pretreatments of the same bone material did not result in reduction of the ages for even severely degraded bone material. Pretreatment removes contamination, allowing radiocarbon dating to be a useful tool.

f. Shellac type preservatives, if present, could yield a much younger RC age for coated bone samples. However, none of our samples from 1990 on had such coatings. For example, scrapings from bone fragment surfaces of the Allosaurus and Acrocanthosaurus were tested on a Leco furnace analyzer for carbon content yielding $2.7 \%$ and $3.3 \%$ carbon, respectively,whereas the surface of an Edmontosaurus fragment containing $2.7 \%$ carbon gave $18.1 \%$ and $51.8 \%$ carbon content with one and three coats of shellac, respectively. However, PVC-coated specimenstended to give false older ages. Ononeoccasion wehad the lab pretreattoremove the PVC coating from outer bone.

g. The Reservoir Effect can cause older ${ }^{14} \mathrm{C}$ ages than are true, as evidenced by a living tree at a German airport giving an $\mathrm{RC}$ age of $28.8 \mathrm{pMC}$, or 10,000 years [Huber, 1958], and living plants from Montezuma Well in Arizona yielding 11.8 to $4.5 \mathrm{pMC}$, or 17,300 to $24,750{ }^{14} \mathrm{C}$ years BP [Ogden, 1967]. The effect is due to ingestion of gas containing old carbon.

h. Hot dilute acetic acid was employed by all labs on bone fragments to remove adsorbed burial carbonates as a preliminary pretreatment step.

i. $\quad$ ABA pretreatment was used when total bone organics or whole bone was to be $\mathrm{RC}$ dated.

j. Collagen was extracted using the conventional Arslanov method, with the resultant collagen weighed and then tested when available. This was done for samples from Triceratops $\# 1$ and $\# 2$ and Hadrosaur $\# 2$. Because collagen in these was very low or none-existent, bioapatite fractions (two or more) were tested for ${ }^{14} \mathrm{C}$ in the Acrocanthosaurus, Triceratops $\# 1$, and $\# 2$, Hadrosaur $\# 1$ and $\# 2$, and Psittacosaurus. Only the carbonate of bioapatite was RC dated for Hadrosaur\#3, Allosaur and Stegosaurus, with RC ages well within the AMS dating limit.

k. In-situ biological carbonate fraction was extracted with strong but diluted $\mathrm{HCl}$ under vacuum after pretreatment with Acetic acid to remove burial carbonate, and eight dinosaurs yielded reproducible RC ages well within the limits of the AMS and Beta systems. The total bone sample for Hadrosaur \#1 from Alaska was ABA pretreated and then tested for ${ }^{14} \mathrm{C}$, as was the humic acid contaminant, which appeared to be older than the bone itself.

1. Cluster decay, if large amounts of $\mathrm{U}$ and $/ \mathrm{or}$ Th are present, might cause $\mathrm{N}$ in collagen to change into ${ }^{14} \mathrm{C}$, but, not at such low concentrations of $0.020 \mathrm{mg} / \mathrm{kg}$ for Uranium and $0.078 \mathrm{mg} / \mathrm{kg}$ for Thorium(our data from Test America, 2012).

m. Incomplete removal of contaminants would be produce very young RC dates, but the concordance of results from 9 different dinosaurs plus the mosasaur from Belgium [Lindgren et al., 2011], confirmed by dating various fractions, appear to rule out residual contamination.

n. Shellac-type protective coatings could be on bones from museums collected in the late $19^{\text {th }}$ and early $20^{\text {th }}$ centuries. Thus it is necessary to pretreat these bones with hot organic solvents before dating. The AMS lab did this for the Psittacosaurus tail bone containing possible shellac and glue, and Triceratops \#2 outer bone containing PVC coating (used in modern times by paleontologists). These RCages were in the samerange as those for other bone fractions.

o. Bacteria and bacterial products, postulated as a reason for the 24,600 RC year age for the mosasaur from Belgium [Lindgren etal., [2011], would have been removed by ABApretreatment used by Lund University, as noted in the study. Thistypically appliesto all bonestested atstandard ${ }^{14} \mathrm{Claboratories}$. Fungus would also be removed by the ABA pretreatment.

Table 7. Known \& Unknown Contaminants in Dinosaur Bone Samples

\begin{tabular}{|c|c|c|c|c|c|}
\hline Dinosaur & $\begin{array}{c}\text { Lab/method/fraction } \\
\text { Report }\end{array}$ & ${ }^{14} \mathrm{C}$ years $\mathrm{BP}$ & $\delta^{13} \mathrm{C} / \mathrm{pMC}$ & Discovery Date & Location \\
\hline $\begin{array}{c}\text { Hadrosaur \#2 Unknown } \\
\text { contaminant [sample was too small } \\
\text { at } 2.7 \mathrm{~g} \text {; next sample was } 57 \mathrm{~g}\end{array}$ & $\begin{array}{l}\text { GX-31950- } \\
\text { AMS/col }\end{array}$ & $1950 \pm 50$ & $-23.5 / 78.4$ & $01 / 18 / 2006$ & MT \\
\hline $\begin{array}{c}\text { Hadrosaur \#2 Humic acid } \\
\text { contaminant was isolated from the } \\
\text { alkaline pretreatment solution and } \\
\text { dated. }\end{array}$ & $\begin{array}{c}\text { UGAMS- } \\
\text { 01938/AMS/hum }\end{array}$ & $2,560 \pm 70$ & $-21.5 / 72.7$ & $04 / 10 / 2007$ & MT \\
\hline $\begin{array}{l}\text { Psittacosaur } \\
\text { Burial carbonate was the known } \\
\text { contaminant from the acetic acid } \\
\text { pretreatment. It can be either } \\
\text { younger or older than the bone, and } \\
\text { is removed by hot } \\
\text { dilute acetic acid under vacuum and } \\
\text { then }{ }^{14} \mathrm{C} \text { dated. }\end{array}$ & $\begin{array}{c}\text { UGAMS- } \\
\text { 8824/AMS/Carb }\end{array}$ & $4,017 \pm 50$ & $-7.2 / 60.6$ & $05 / 31 / 2011$ & China \\
\hline
\end{tabular}

The pMC's derived from "blanks" vary from one laboratory to another. Considering the findings of [10], the sterility of the blanks themselves is in question. Additional measures beyond standard chemical pretreatment have been used to provide an extra level of confidence, particularly oxidation and reduction. For example, [31] used an acid-base-wet oxidation pretreatment. They oxidized graphite and reduced it again, obtaining a pMC of $0,04 \pm 0.02$, using oxygen as the oxidant rather than copper oxide, which can introduce contamination during the combustion of samples. These tests show that any contamination introduced by AMS operations is likely to be miniscule in relation to the pMC levels obtained for the dinosaur bone samples in Table 1 that range between 6.45 to $0.61 \mathrm{pMC}$, or
$22,020 \pm 50$ to $41,000 \pm 220{ }^{14} \mathrm{C}$ years BP. Our results are not merely anomalies but are reproducible data, pointing to a much younger geologic column, an observation that has not yet been recognized by other methods for assessing chronology.

\section{The importance of sedimentology}

So-called "megaflood" deposits are thick sedimentary layers displaying a variety of morphologies over wide areas that are the product of large scale, high velocity floods [32], [33] "Sedimentology analysis and reconstruction of sedimentation conditions of the Tonto Group [Grand Canyon] reveals that deposits of different stratigraphic sub-divisions were formed simultaneously in different litho-dynamical 
zones of the Cambrian paleobasin." [34] showed that sediments formed simultaneously by size and density in moving waters spontaneously in the disastrous Bijou Flood in Colorado of 1965. "Thus, the stratigraphic divisions of the geological column founded on the principles of Steno do not correspond to the reality of sedimentary genesis" [35] This has been confirmed by experiment [36], [37](see Figure 2). [38] found the large cross-beds of the Coconino sandstones of the Grand Canyon difficult to explain within current aeolian models and they suggest that a significant part of the Coconino may have been formed under water. Mudstones such as shale compose about $62 \%$ of the geologic column. They are generally considered to have formed slowly in the quiet environment of ancient lakes. However, flume experiments show that mudstones can form in moving waters [39]. Radiocarbon dating of shale containing $10.88 \%$ carbon from a quarry in Colorado's Eocene Green River Formation yielded a pMC of 0.37 , or a ${ }^{14} \mathrm{C}$ age of $45,130 \pm$ $270{ }^{14} \mathrm{C}$ years BP (Table 2, \#13) and $\delta^{13} \mathrm{C}$ of -31.6 in 2010 on University of Georgia's AMS equipment, which is reliable to $0.11 \mathrm{pMC}$, or 55,000 ${ }^{14} \mathrm{C}$ years $\mathrm{BP}$.
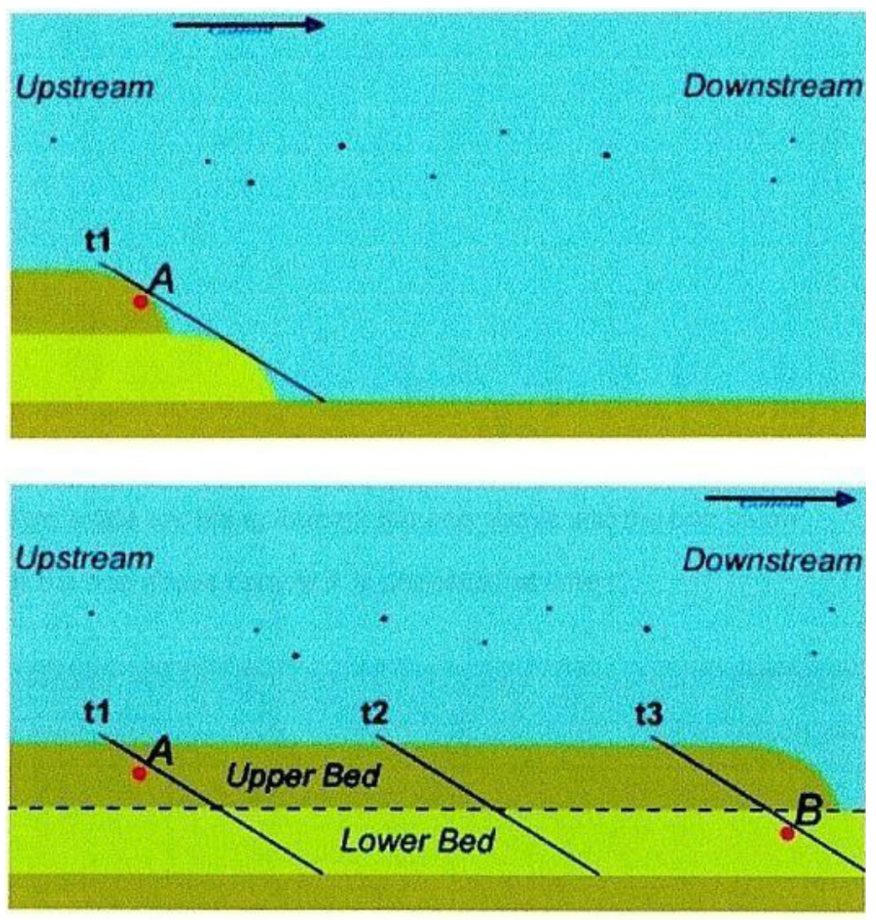

Figure 2. How sediments form in moving waters. Fossil A in the upper bed is buried nearsimultaneously with Fossil B in the lower bed.

The above figure was drawn from lab and flume studies: Makse et al., 1997 [34]; Berthault, 2002 [35]. Schieber and Southard, 2009 [39] found that mudstones formed in moving waters rather than in the bottom of stationary lakes. Over $60 \%$ of sedimentary rocks are mudstone.

\section{Conclusion}

\section{A wake-up call to Earth}

The explosion of the Chelyabinsk meteorite over Russia in 2013 that injured over 1000 people has intensified interest in determining more accurate asteroid numbers, orbits, and collision frequency with Earth. [1] along with this study, recognize a much higher meteorite impact risk due to significantly shorter intervals between encounters with Earth than are commonly presumed. This calls for revisiting cratering chronology and the development of systems to protect life on Earth. Unlike long-age radioisotope dating, ${ }^{14} \mathrm{C}$ - dating has been calibrated against known artifacts, tree rings, and annual lake sediments out to 52,800 years [40]. ${ }^{14} \mathrm{C}$ dating of fossils is thus a chronology tool that can help agencies such as NASA and NSF adjust models that estimate the hazard of encountering Near-Earth Objects. The anomalous but consistent finding that a variety of fossils buried throughout the Phanerozoic actually contain ${ }^{14} \mathrm{C}$ suggests a much younger geologic column. These anomalies are found in fossils that should contain zero ${ }^{14} \mathrm{C}$,including, wood, amber, coal, dinosaurs, and even diamonds. The ${ }^{14} \mathrm{C}$ dating of dinosaurs presented here reinforces similar ${ }^{14} \mathrm{C}$ data presented by [1].

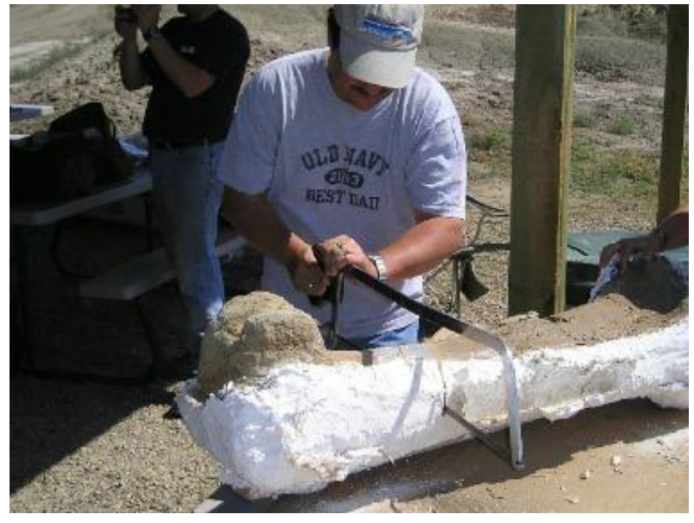

(a)

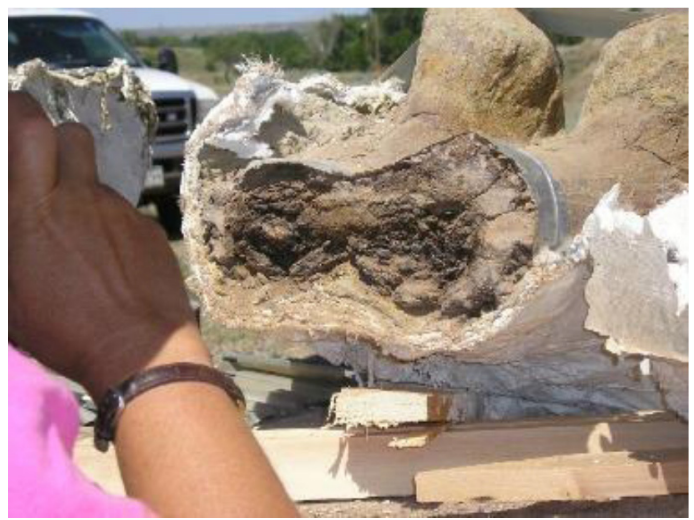

(b)

Figures 3a and 3b. Sawing Triceratops\#1 femur bone to extract samples for ${ }^{14} \mathrm{C}$ dating from cross section.

\section{Our tentative conclusions are:}

1. The 65 to 150 million year ages attributed to dinosaurs are apparently erroneous.

2. The 45 million years between the Late Cretaceous and Late Jurassic epochs are also mistaken, since dinosaur fossils and coal from these strata exhibit equivalent ${ }^{14} \mathrm{C}$ ages.

3. Dinosaurs apparently coexisted with both Neanderthal and Modern man for a period of time. Distinct dinosaur depictions exist world-wide, apparently because contemporaneous people actually saw them. For example, see Figures 5 and 6. 
4. The diverse evidence provides a simple explanation for the survival of soft tissue and bio-molecules in some dinosaur fossils, beyond any possible contribution of biofilm and blood iron. Such complex organic substances should not survive burial past 100,000 years [41], [42].

5. The $19^{\text {th }}$ century hypothesis that sedimentary formations took millions of years to form is clearly contradicted by ${ }^{14} \mathrm{C}$ ages for Neanderthals, wood, coal, amber, shale and dinosaur bones as well as with studies of sedimentary deposits in moving water, including mudstone. These studies demonstrate simultaneous deposition of multiple strata in rapidly moving water [Figure 2]. This leads to the possibility that extensive sedimentary formations were deposited by one or more cataclysmic events only thousands of years ago rather than millions.

6. The minute amounts or absence of collagen found in dinosaur bones could be at least partially attributed to their burial in megaflood deposits, with associated leaching, so that only the $\mathrm{CaCO} 3$ of bioapatite could be ${ }^{14} \mathrm{C}$ dated.

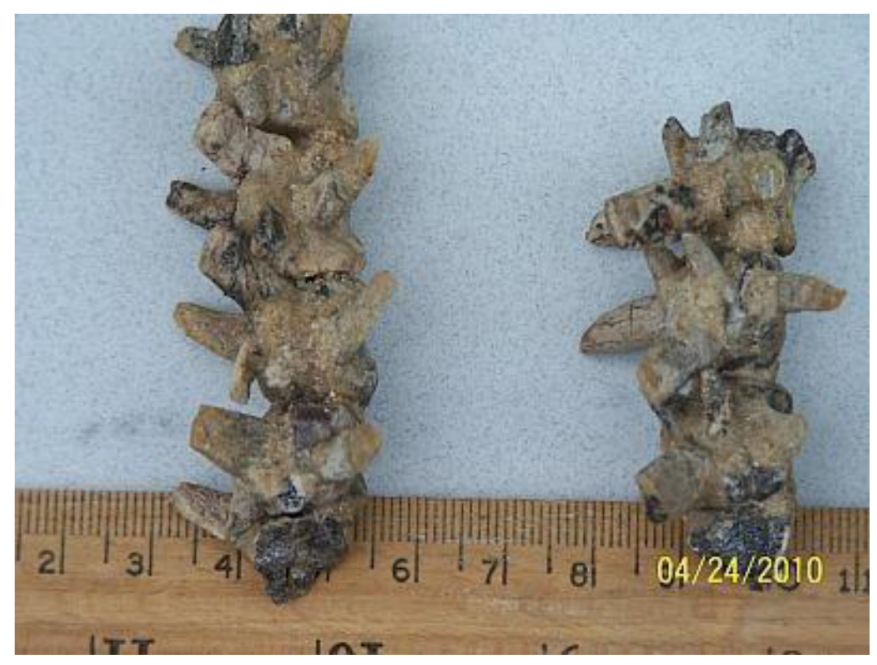

Figure 4. Psittacosaurus tail bone from the Gobi Desert, China.

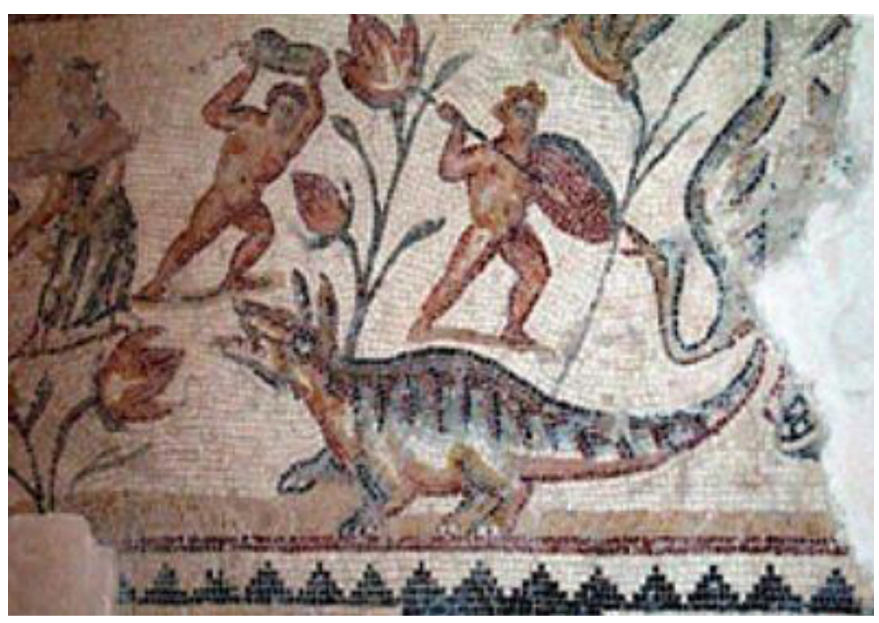

Figure 5. Possible Ceratopsid dinosaur on a mosaic floor in Sepphoris, Israel, 300 AD.

\section{Implications and the need for further research}

The data displayed in our Figures and Tables clearly demonstrate the ubiquitous presence of ${ }^{14} \mathrm{C}$ in geologic formations where there should be none, if prevailing ideas of Earth history are correct. In order to confirm this unexpected ${ }^{14} \mathrm{C}$ content, researchers need to date a much larger cross section of diamonds and fossils from around the world to accurately characterize and understand this phenomenon. Using ${ }^{14} \mathrm{C}$-dating of samples from different parts of the entire geologic column will help discover patterns of ${ }^{14} \mathrm{C}$ retention and arrive at a coherent explanation of the results. To date, at least 185 subaerial meteorite impacts have been identified on Earth. Assuming a random distribution, there would have been an additional 430 impacts in the oceans, which compose $70 \%$ of the Earth's surface; but over what time period? These are in addition to meteors exploding above the surface. An impact off the New Jersey coast sent a 20 m-high wave up the Hudson River [43] and an impact in the Chesapeake Bay caused a 500 m-high tsunami [44]. [45] have formally explored "geomythology", which matches physical evidence of catastrophic events with reports of these events hidden in the oral and written traditions of ancient societies. We recommend inclusion of ${ }^{14} \mathrm{C}$ dating of core samples of paleo-tsunami deposits as evidence when trying to establish the timing of events. Science advances by addressing anomalies. The world will be well served by further investigating evidence that at least a portion of the geological time scale should be condensed, which threatens a higher risk to Earth of meteorite impact.

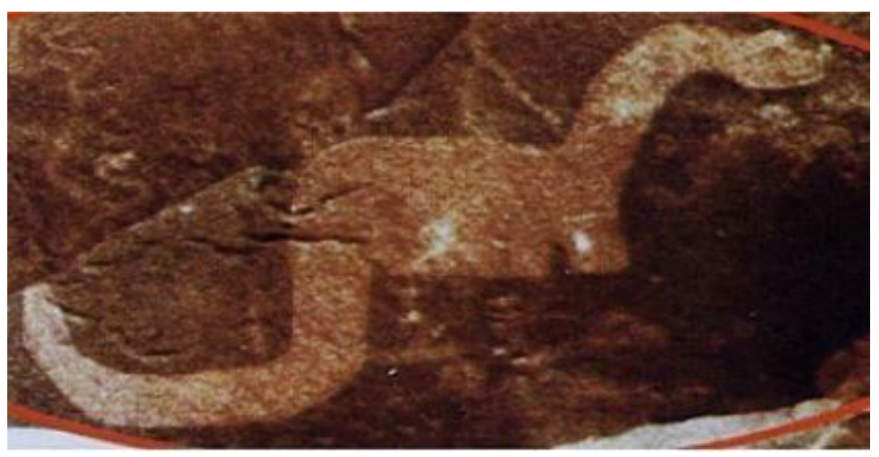

Figure 6. Anasazi Indian dinosaur petroglyph circa 500 AD, Kachina Bridge, Natural Bridges National Monument, Utah.

\section{Acknowledgements}

The original radiocarbon dating reports from the four laboratories listed for the 11 dinosaurs in Table 1 and the radiocarbon dating reports listed in Table 2 for fossil wood etc., and in Table 3 can be seen here: Original Lab Reports. Funding was from private sources. There is no conflict of interest. The data cited in Tables 4 and 5 can be found in [1] and [8]Thanks are extended to all the members of our current and past teams, for without their help it would have been much more difficult to present these data. In particular we wish to recognize the suggestions and editing of physicist J. Satola, the advice of T. Clarey regarding $\delta{ }^{13} \mathrm{C}$, valuable contributions from physicist T. Seiler, and the patience and persistence of V. Miller and M. Fischer in assembling this report. We also acknowledge many dedicated contributors who supplied both financial support and valuable suggestions. 


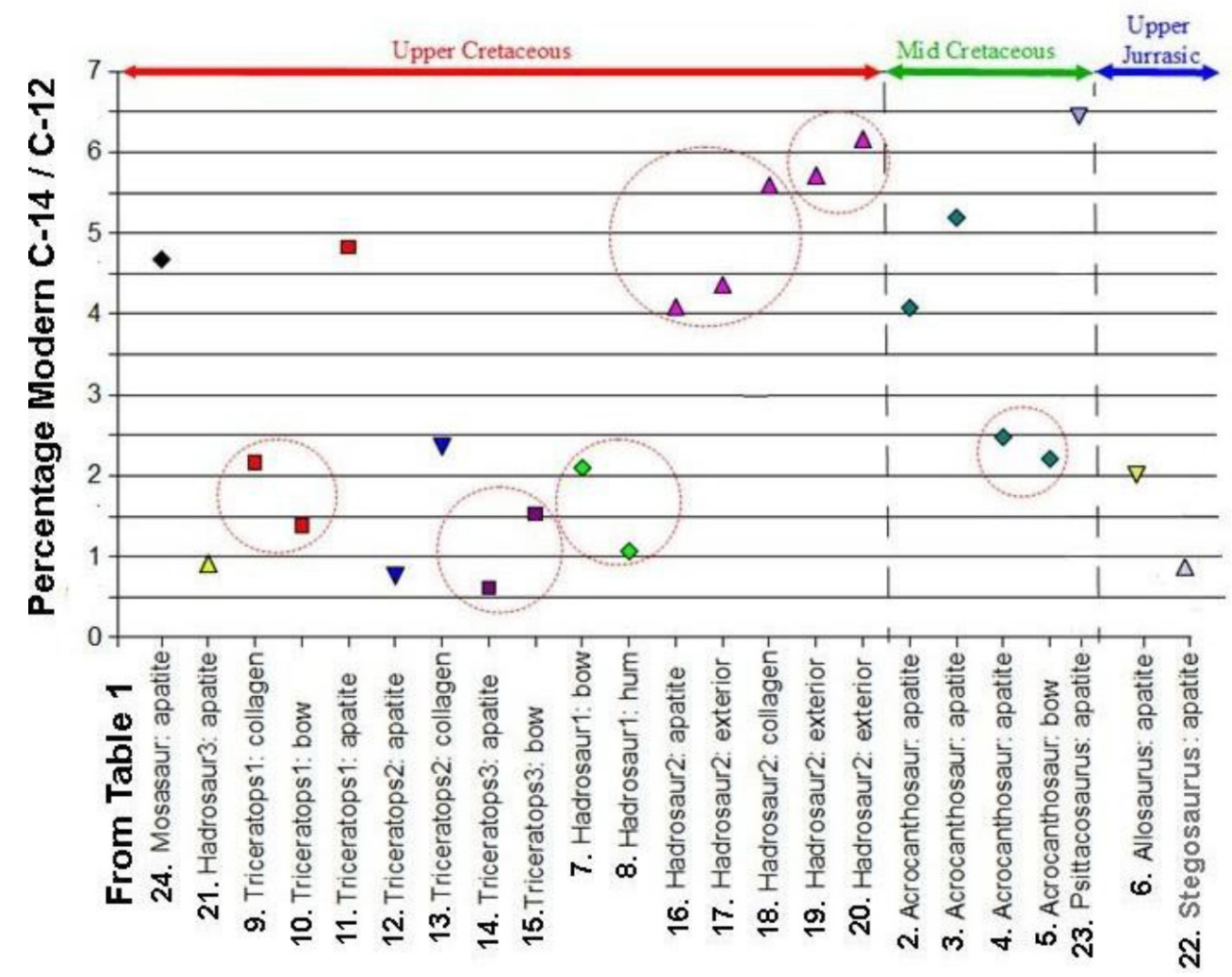

Figure 7. Concordance among dinosaur bone fractions demonstrates a lack of contamination.

\section{References}

1. Baumgardner JR, Humphreys DR, Snelling AA, Austin SA (2003) The Enigma of Ubiquity of ${ }^{14} \mathrm{C}$ in Organic Samples Older Than 100 ka. AGU Fall Meeting Abstracts, abstract \#V32C-1045.

2. Lindgren J, Uvdal P, EngdahlA, LeeAH, Alwmark C et al. (2011) Microspectroscopic Evidence of Cretaceous Bone Proteins. PLOS ONE 6: 8-9.

3. Schweitzer MH, Wittmeyer JL, Horner JR, Toporski JK (2005) Soft-Tissue Vessels and Cellular Preservation in Tyrannosaurus rex. Science 307: 1952-1955.

4. Schweitzer MH, Zheng W, Organ CL, Avci R, Suo Z (2009) Biomolecular Characterization and Protein Sequences of the Campanian Hadrosaur $B$. Canadensis. Science 324:626-631.

5. Holzschuh J, Pontcharra J de, Miller H (2012) Recent C-14 dating of fossils including dinosaur bone collagen. Are theresults a confirmation of rapid formation of the geologic column as modern sedimentology studies have predicted?. In: von Brandenstein-Zeppelin AG, von Stockhausen A (eds.). Evolution Theory and the Sciences: A Critical Examination. Pg 295-321, Gerhard Hess Verlag, Bad Schussenried, Germany.

6. Hedges EEM (1992) Sample treatment strategies in radiocarbon dating. In: Taylor RE, Long A, Kra RS (eds.). Radiocarbon after four decades. (1stedn), Pg 166-167, Springer Verlag, New York.

7. Arslanov Kh A, Svezhentsev Yu S (1993) An improved method for radiocarbon dating fossil bones. Radiocarbon 35: 387-391.

8. McManamon FP (2004) NPS Archeology Program: Kennewick Man. Memorandum from the United States Department of the Interior, National Park Service.

9. Dawson JW (1846) Notice of some Fossils found in the Coal Formation of Nova Scotia. Quarterly J. Geol. London 2: 132-136.

10. Taylor RE, Southon J (2007) Use of natural diamonds to monitor ${ }^{14} \mathrm{C}$ AMS instrument backgrounds. Nuclear Instruments and Methods in Physics Research B 259: 282-287.

11. Sheppard JC, Chatters RM (1976) Washington State University Natural Radiocarbon Measurements II. Radiocarbon 18: 140-149.

12. Stuckenrath R, Mielke JE (1973) Smithsonian Institution Radiocarbon Measurements VIII. Radiocarbon 15: 388-424.

13. Stuckenrath R, Mielke JE (1972) Smithsonian Institution Radiocarbon Measurements VII. Radiocarbon 14: 401-412.
14. Berger R, Libby W F (1968) UCLA Radiocarbon Dates VIII. Radiocarbon 10(2): $402-416$.

15. Harrington CR, Morlan RE (2002) Evidence for Human Modification of a late PleistoceneBison from the Klondike District, Yukon Territory, Canada. Arctic. Inst. N. Am. 55: 143-147.

16. Zorich Z (2010) Should We Clone Neanderthals?. Archaeology 63: 34-41.

17. Rink WJ, Schwarcz HP, Valoch K, Seitl L, Stringer CB (1996) ESR Dating of Micoquian Industry and Neanderthal Remains at Kulna Cave, Czech Republic. Journal of Archaeological Science 23: 889-901.

18. Vasil'chuk Y, Punning JM, Vasil'chuk A (1997) Radiocarbon ages of mammoths in Northern Eurasia: implications for population development and Late Quaternary environment. Radiocarbon 39: 1-18.

19. Thompson KM, Agenbroad LD (2005) Bone distribution and diagenetic modificationsat the mammoth site of Hot Springs, South Dakota, USA. Geological Society of America Abstracts with Programs, 37(7), 116.

20. Ostrom PH, Macko SA, Engel MH, Russell DA (1993), Assessment of trophic structure of Cretaceous communities based on stable nitrogen isotope analyses. Geology 21: 491-494.

21. Kosmowska-Ceranowicz B, Giertych M, Miller H (2001), Cedarite from Wyoming: Infrared and Radiocarbon Data. Prace Muzeum Ziemi 46: 77-80.

22. Cherkinsky A (2009) Can we get a good radiocarbon aged from "Bad Bone?" Determining the reliability of radiocarbon age from bioapatite. Radiocarbon 51: 647-655.

23. Zazzo A, Saliege JF (2011) Radiocarbon dating of biological apatites: A review. Palaeogeo. Palaeoclim. Palaeoeco 310: 52-61.

24. Kutschera, W. (2001), 4.4 Radiocarbon dating of the Iceman Otzi with accelerator mass spectrometry, VERA Laboratory, Institute for Isotopic Research and Nuclear Physics, University of Vienna, pp. 1-9.

25. Collins MJ, Nielsen-Marsh CM, Hiller J, Smith CI, Roberts JP (2002) The survival of organic matter in bone: a review. Archaeometry 44: 383-394.

26. Buhay WM, Chinique de Armas Y, Rodriguez Suarez R, Arredondo C, Smith DG, et al. (2013) A preliminary carbon and nitrogen isotopic investigation of bone collagen from skeletal remains recovred from a pre-Columbian burial site, Matanzas Province, Cuba. Applied Geochemistry 32: 76-84.

27. Ogden JG III (1967) Radiocarbon and pollen evidence for a sudden change in climate in the Great Lakes Region 10,000 years ago. In: Cushing EJ, Wright HE (eds.). Quarternary Paleoecology. Pg 117-127, Yale University Press, New Haven, CT. 
Hugh Miller, Robert Bennett, Jean de Pontcharra, Maciej Giertych, Marie C. van Oosterwyck-Gastuche et al. (2019) The Search for Solutions to Mysterious Anomalies in the Geologic Column

28. Huber B (1958) Recording gaseous exchange under field conditions. In: Thimann KV (ed.). The Physiology of Forest Trees. Pg. 187-195, Ronald Press, New York.

29. Cherkinsky A, Chataigner $\mathrm{C}(2010){ }^{14} \mathrm{C}$ Ages of Bone Fractions From Armenian Prehistoric Sites. Radiocarbon. 52: 569-577.

30. Zazzo A (2014) Bone and enamel carbonate diagenesis: A radiocarbon prospective. Palaeogeogr. Palaeoclimatol. Palaeoecol 416: 168-178.

31. Bird MI, Ayliffe LK, Fifield LK, Turney CSM, Cresswell RG, et al. (1999) Radiocarbon dating of "old" charcoal using a wet oxidation, stepped-combustion procedure. Radiocarbon 41: 127-140.

32. Carling PA (2013) Freshwater megaflood sedimentation: What can we learn about generic processes?. Earth-Science Reviews 125: 87-113.

33. Berthault G (2004) Sedimentological interpretation of the Tonto Group stratigraphy (Grand Canyon Colorado River). Lithology and Mineral Resources 39: 480-484.

34. McKee ED, Crosby EJ, Berryhill HL (1967) Flood deposits, Bijou Creek, Colorado, June 1965 . Journal of Sedimentary Research. 37:829-851.

35. Berthault G (2002) Geological dating principles questioned. Paleohydraulics: a new approach. Journal of Geodesy and Geodynamics 22: 19-26.

36. Makse HA, Havlin S, King PR, Stanley HE (1997), Spontaneous stratification in granular mixtures, Nature. 386: 379-382.

37. Julien PY, Lan Y, Berthault G. (1993) Experiments on Stratification of Heterogeneous Sand Mixtures. Bull. Soc. Geol. France 164: 649-660.
38. Maithel SA, Brand L R, Whitmore JH (2013) Morphology of Avalanche Beds in the Coconino Sandstone at Chino Wash, Seligman, Arizona. Geological Society of America 45.

39. Schieber J, Southard JB (2009) Bedload transport of mud by floccule ripples Direct observation of ripple migration processes and their implications. Geology 37: 483-486.

40. Ramsey CB, Staff RA, Bryant CL, Brock F, Kitagawa H et al. (2012) A Complete Terrestrial Radiocarbon Record for 11.2 to 52.8 kyr B.P. Science 338: 370-374.

41. Bada J L, Wang X S, Hamilton H (1999) Preservation of key biomolecules in the fossil record: current knowledge and future challenges. Phil Trans of the Royal Soc B: Biol Sci 354: 77-87.

42. Nielsen-Marsh C (2002) Biomolecules in fossil remains - Multidisciplinary approach to endurance. Biochemist 24: 12-14.

43. Abbott DH, Cagen KT, Carbotte SM, Nitsche FO, West A, et al. (2010) Tsunami in the Hudson 2300 BP-Have We Found the Oceanic Source Crater?, Eos Trans. AGU, 91(26), Meet. Am. Suppl., Abstract NH32A-04.

44. Collins GS, Wünnemann K (2005) How big was the Chesapeake Bay impact? Insight from numerical modeling. Geology 33: 925-928

45. Masse B, Barber EW, Piccardi L, Barber PT (2007) Exploring the nature of myth and its role in science, Geological Society London Special Publications. 273: 9-28.

\section{Citation:}

Hugh Miller, Robert Bennett, Jean de Pontcharra, Maciej Giertych, Marie C. van Oosterwyck-Gastuche et al. (2019) The Search for Solutions to Mysterious Anomalies in the Geologic Column. Geol Earth Mar Sci Volume 1(1): 1-15. 